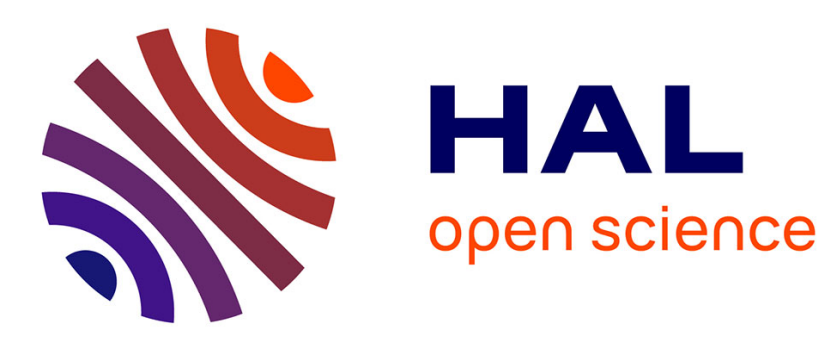

\title{
Shear bearing capacity of RC slabs without shear reinforcement: Design codes comparison
}

\author{
W. Nana, Tan Trung Bui, M. Bost, A. Limam
}

\section{To cite this version:}

W. Nana, Tan Trung Bui, M. Bost, A. Limam. Shear bearing capacity of RC slabs without shear reinforcement: Design codes comparison. KSCE Journal of Civil Engineering, 2019, 23 (1), pp.321-334. 10.1007/s12205-018-0612-7 . hal-02069657

\section{HAL Id: hal-02069657 https://hal.science/hal-02069657}

Submitted on 15 Jan 2020

HAL is a multi-disciplinary open access archive for the deposit and dissemination of scientific research documents, whether they are published or not. The documents may come from teaching and research institutions in France or abroad, or from public or private research centers.
L'archive ouverte pluridisciplinaire HAL, est destinée au dépôt et à la diffusion de documents scientifiques de niveau recherche, publiés ou non, émanant des établissements d'enseignement et de recherche français ou étrangers, des laboratoires publics ou privés. 


\title{
Shear bearing capacity of RC slabs without shear reinforcement:
}

\section{Design codes comparison}

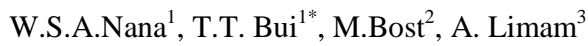 \\ ${ }^{1}$ University of Lyon, INSA Lyon, GEOMAS, France. \\ ${ }^{2}$ GERS-RRO, Ifsttar Bron, Bron, France \\ ${ }^{3}$ University of Lyon, France.
}

*Corresponding authors:

E-mail address: wendpanga-serge-auguste.nana@insa-lyon.fr; tan-trung.bui@insa-lyon.fr; ali.limam@insa-lyon.fr

\begin{abstract}
For reinforced concrete structures, as beams, slabs or walls, failure under bending is well known and its description and design is relatively internationally agreed. However for the shear failure phenomenon, there is not yet a common agreement at the international level, no consensus is reached on the subject at this time. Many parameters are involved in the shear resistance mechanism and many phenomena coexist. The shear force transfer mechanisms are sometimes complex and difficult to discern. By analyzing the different shear design codes, some shear parameters are taken into account and ignored by others, which makes that a shear effect may be omitted. In addition, different ways are adopted to take into account the different shear parameters. The main purpose of this study is to help the engineering by presenting a comparative study of all the main analytical models for the determination of shear capacity: The EN 1992-1-1:2005 standard (EC2) (CEN, 2005), French National Annex (FD P 18-717, 2013), ACI 318-14 (ACI Comittee 318, 2014), fib Model Code 2010 (Fib Model Code 2010, 2012) using level of approximation LoA I and LoA II and (CSA Committee A23.3, 2004) both Modified Compression Field Theory (MCFT) based models, and finally the Critical Shear Crack Theory (CSCT) which is the basis of the Swiss
\end{abstract}


standard SIA 262 (SIA 262, 2003) are all examined. The results obtained are discussed regarding their agreement with eighteen shear experimental results on thick slabs $(30 \mathrm{~cm}, 35 \mathrm{~cm}$, and $40 \mathrm{~cm})$ and thin slabs $(10 \mathrm{~cm})$ without shear reinforcement.

Keywords: reinforced concrete slabs; shear strength; standards results; experimental results

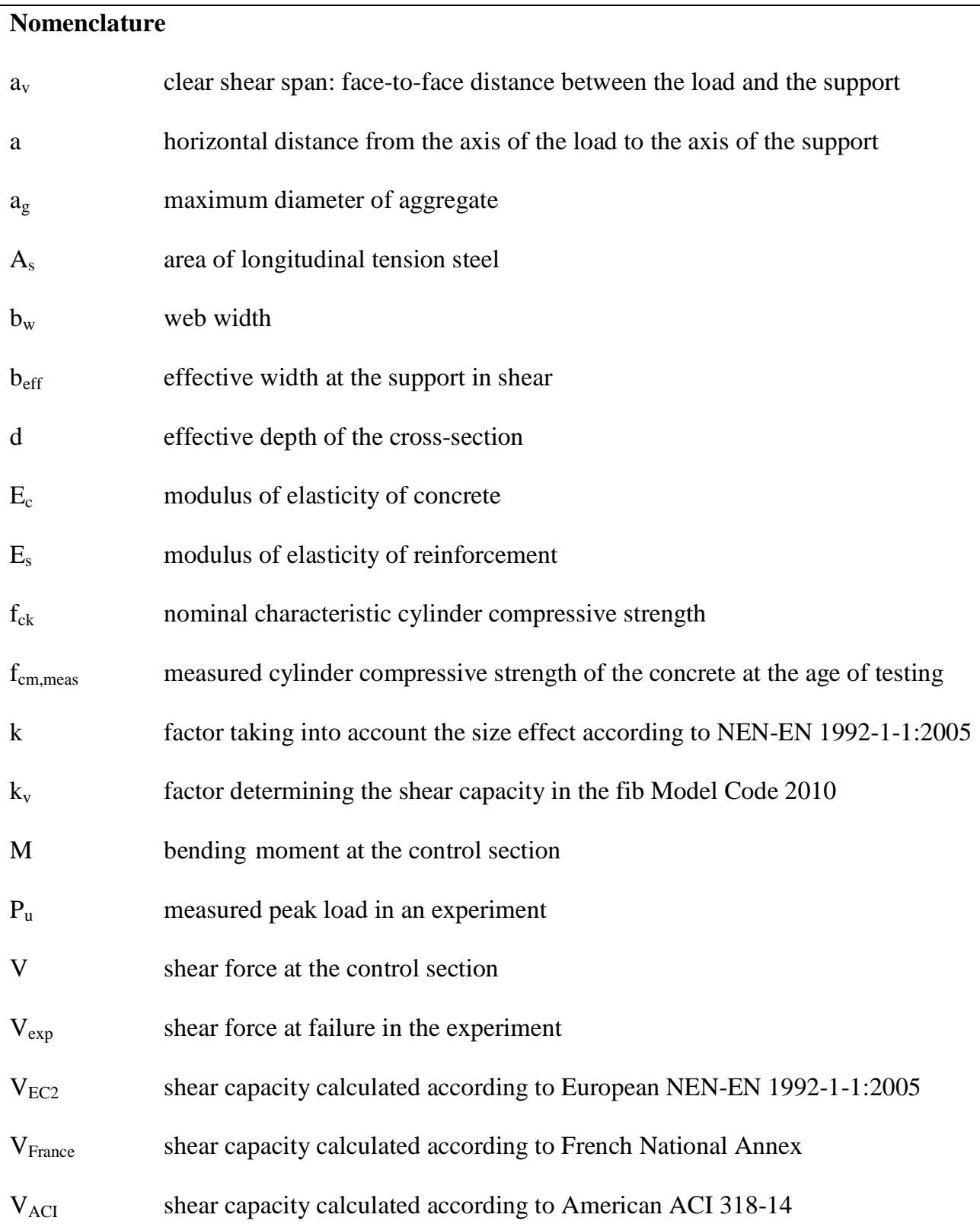




\begin{tabular}{|ll|}
\hline $\mathrm{V}_{\mathrm{MCFT}}$ & shear capacity calculated according to Modified Compression Field Theory \\
$\mathrm{V}_{\mathrm{MC}}$ & shear capacity calculated according to fib Model Code 2010 \\
$\mathrm{~V}_{\mathrm{CSA}}$ & shear capacity calculated according to Canadian CSA A23.3-04 \\
$\mathrm{V}_{\mathrm{CSCT}}$ & shear capacity calculated according to Critical Shear Crack Theory \\
$\beta$ & aggregates interlocking factor in the MCFT \\
$\beta_{\mathrm{EC} 2}$ & factor taking into account arching action in European practice \\
$\varepsilon$ & strain in the fib-Model Code 2010 control depth \\
$\varepsilon_{\mathrm{x}}$ & concrete partial safety factor in European practice \\
$\gamma_{\mathrm{c}}$ & effective crack spacing accounting for aggregate size in the fib Model Code 2010 \\
$\mathrm{~s}_{\mathrm{xe}}$ & ratio of flexural reinforcement in the longitudinal direction \\
$\rho_{\mathrm{l}}$ &
\end{tabular}

\section{Introduction}

Structural concrete standards provide recommendations for calculating the shear strength of reinforced concrete (RC) slabs or beams are based on various parameters affecting shear strength. These parameters influence various mechanisms that jointly support the shear forces. The understanding of these different mechanisms or transmission modes of shear force which act in cracked concrete is a key element for the study of shear failures of RC members. Due to cracking, several shear mechanisms must be activated in order to guarantee the loads transmission to the supports. The shear strength of RC slabs and beams is ensured by the following main mechanisms (ASCE-ACI Committee 445 on Shear and Torsion, 1998): the shear stresses in uncracked concrete which involves the concrete compressive strength, the interlocking effect of aggregate which involves the aggregate size, the dowel action which involves the amount of longitudinal reinforcement, the residual tensile stresses, and an eventually arching effect. The shear parameters 
considered by the codes for estimating shear strength are those related to materials, such as concrete compressive strength, aggregates size, longitudinal reinforcement ratios, geometric parameters such as the ratio $a_{v} / d$, then the member depth related to size effect phenomenon. For having safe and economical design rules, it is important to have a solid understanding of the shear behaviour of RC structures. However this is difficult because many parameters are involved in the resistance mechanism and many phenomena coexist there. In addition, the shear force transfer mechanisms are sometimes complex and difficult to discern. The complexity of the problem widely debated since the last century (Joint Committee on Concrete and Reinforced Concrete, 1916), (Balázs, 2010), (Marí et al., 2015) explains why there is still no unified and completely realistic theory of shear behavior of slabs and beams and that the calculation methods adopted by engineering communities are often empirical or semi-empirical.

From the examination of shear design standards, no consensus is reached allowing determining the shear capacity of RC structures in the best way. There is not yet a common agreement on the important shear parameters (Shioya et al., 1990), (Brown et al., 2006), the shear mechanisms (Bažant et al., 2007), (Collins et al., 2008) and therefore the best standard. Depending on the standards, as illustrated in Table 1, the effect of some shear parameters which intervene in the resistance mechanism is omitted, consequently abandoning eventually a shear aspect in the Supprimé: Table 1 capacity calculation. In addition, the standards adopt different ways to take into account the different shear parameters. Some models for calculating shear strength are quite readily distinguishable from one another: the European standard EC2 (CEN, 2005), the French National Annex FNA (FD P 18-717, 2013), the American standard ACI (ACI Committee 318, 2014), the Canadian standard CSA (CSA Committee A23.3, 2004), the fib Model Code (Fib Model Code 2010, 2012), the Swiss standard SIA (SIA 262, 2003). These standards are for the most part based on different theoretical methods or researchers approaches. The European standard EC2 and American standard ACI 318 of an empirical nature are based on Regan's works (Regan, 1987) and 
(Bresler and MacGregor, 1967) works respectively. The Canadian standard CSA23.3 and fib Model Code 2010 are both derived on the Modified Compression Field Theory MCFT of (Vecchio and Collins, 1986) and the Swiss standard SIA 262 derives from the Critical Shear Crack Theory CSCT of (Muttoni, 2003). Both MCFT and CSCT based calculation models are physical (mechanical) models based on strain notion resulting in the opening of a critical shear crack and could provide a common approach for shear design. Such a method takes into account the crack lips roughness in order to apprehend their ability to transmit shear forces through aggregates interlocking effect.

Table 1 : Shear parameters considered depending on the standards

\begin{tabular}{|c|c|c|c|c|c|c|}
\hline Parameters & EC2 & FNA & ACI & CSA & SIA & Fib Model Code \\
\hline$\square$ Compressive strength: fc & D & 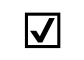 & $\nabla$ & $\nabla$ & $\nabla$ & $\nabla$ \\
\hline$\square$ Aggregate size: dmax & Х & $\mathrm{X}$ & Х & $\nabla$ & $\nabla$ & $\checkmark$ \\
\hline$\square$ Ratio: a/d & $\square$ & $\square$ & $\nabla$ & $\nabla$ & $\nabla$ & $\square$ \\
\hline$\square$ Long. reinforcement ratio: $\rho_{1}$ & $\nabla$ & $\mathrm{X}$ & $\nabla$ & $\nabla$ & $\nabla$ & $\nabla$ \\
\hline$\square$ Transv. reinforcement ratio: $\rho_{\mathrm{t}}$ & 区 & Х & $\bigotimes$ & 凶 & $\mathrm{X}$ & $\mathrm{X}$ \\
\hline$\square$ Size effect related to depth: $\mathrm{d}_{l}$ & $\nabla$ & $\mathrm{X}$ & $\mathrm{X}$ & $\nabla$ & $\nabla$ & $\nabla$ \\
\hline \multicolumn{7}{|c|}{$\square$ : The parameter is taken into account by the standard } \\
\hline
\end{tabular}

The main purpose of this study is to help the engineering by focusing on the different predictions provided by all the main shear design provisions in order to formulate recommendations for engineers designing RC slabs without stirrups through analytical investigation. Both the case of thick and thin slabs is studied. The following models for estimating the shear strength of RC slabs are all examined: European (CEN, 2005), French (FD P 18-717, 2013), American (ACI Committee 318, 2014), Model Code (Fib Model Code 2010) with LoA I and LoA II approximation levels, and the Critical Shear Crack Theory (CSCT). Note that the LoA II of the fib 
Model Code 2010 corresponds to the Canadian standard CSA23.3 (CSA Committee A23.3, 2004).

The results obtained are discussed regarding their agreement with experimental results. The tests were carried out by varying on the slabs the different shear parameters, and also examining different slab configurations.

\section{Shear design models}

\subsection{Eurocode 2 (EC2) and French National Annex (FNA) models}

To estimate the shear capacity of a RC cross-section not containing shear reinforcement and without axial load, the European standard EN 1992-1-1: 2005, Section 6.2.2 (CEN, 2005) takes into account the effects of the longitudinal reinforcement ratio $\boldsymbol{\rho}_{\mathbf{l}}$, the concrete compressive strength $\mathbf{f}_{\mathbf{c k}}$, and a size effect through a factor $\mathrm{k}$. Recommendations are also provided to take into account the influence of an eventual arch effect occurring for low values of the ratio $a_{v} / d$. Note that the influence of the concrete aggregates size is omitted. The shear strength is calculated as given by Equation 1 ( $\mathbf{f}_{\mathbf{c k}}$ in $\left.\mathrm{MPa}\right)$. It is an empirical relation, first proposed by (Regan, 1987) on the basis of the experimental results.

$$
\mathrm{V}_{\mathrm{EC} 2}=\operatorname{Max}\left\{\begin{array}{l}
{\left[\mathrm{C}_{\mathrm{Rd}, \mathrm{c}} \cdot \mathrm{k} \cdot \sqrt[3]{100 \cdot \rho_{\mathrm{l}} \cdot \mathrm{f}_{\mathrm{ck}}}\right] \cdot \mathrm{b}_{\mathrm{w}} \cdot \mathrm{d}=\mathrm{V}_{\mathrm{Rd}, \mathrm{c} 1}} \\
{\left[v_{\mathrm{min}}\right] \cdot \mathrm{b}_{\mathrm{w}} \cdot \mathrm{d}=\mathrm{V}_{\mathrm{Rd}, \mathrm{c} 2}}
\end{array}\right.
$$

where:

$$
\begin{gathered}
\mathrm{k}=1+\sqrt{\frac{200}{\mathrm{~d}}} \leq 2.0 \\
\mathrm{C}_{\mathrm{Rd}, \mathrm{c}}=\frac{0.18}{\gamma_{\mathrm{c}}} \\
\rho_{\mathrm{l}}=\frac{\mathrm{A}_{\mathrm{sl}}}{\mathrm{b}_{\mathrm{w} \cdot \mathrm{d}}}<2 \%
\end{gathered}
$$

$\mathrm{k}$ is the size effect factor. When increasing the effective depth $\mathrm{d}$ (in $\mathrm{mm}$ ) its value decreases, thus allowing accounting a size effect phenomenon. $\mathrm{C}_{\mathrm{Rd}, \mathrm{c}}$ is an empirical factor used for characteristic 
shear strength. Its value derives from comparison with experimental results of (Regan, 1987) and a reliability analysis on 176 tests (König and Fischer, 1995). $b_{w}$ is the smallest width of the crosssection (in mm). In the case of slabs under concentrated load, a shear effective width $b_{\text {eff }}$ instead of entire width $b_{w}$ is used.

$v_{\min }$ represents the minimum shear stress that can be carried by the member. Its expression is based on the idea that, for low longitudinal reinforcement ratios, the shear capacity can never be less than the flexural capacity (Walraven, 2013). EN 1992-1-1: 2005 (CEN, 2005) therefore recommends:

$$
v_{\text {min_EC2 }}=0.035 \mathrm{k}^{3 / 2} \sqrt{\mathrm{f}_{\mathrm{ck}}}
$$

However, in the requirements of the French formulation FNA (FD P 18-717, 2013) another approach is adopted to calculate $v_{\min }$ :

$$
v_{\min }=\left\{\begin{array}{l}
0.23 \sqrt{\mathrm{f}_{\mathrm{ck}}} \\
0.053 \mathrm{k}^{3 / 2} \sqrt{\mathrm{f}_{\mathrm{ck}}}
\end{array}\right.
$$

(3) For slabs having an aptitude of transverse redistribution of loads and walls,

(4) For beams and other types of the slab.

Arching action is accounted assuming that the contribution of a load applied within $0.5 \mathrm{~d} \leq \mathrm{a}_{\mathrm{v}} \leq 2 \mathrm{~d}$ to the design shear force $\mathrm{V}_{\mathrm{Ed}}$ may be reduced by the factor $\beta_{\mathrm{EC} 2}=\mathrm{a}_{\mathrm{v}} / 2 \mathrm{~d}$.

\subsection{ACI 318-14 model}

As European standard (CEN, 2005), the American standard (ACI Committee 318, 2014), Section 22.5.5.1, also takes into account the compressive strength of concrete $\mathbf{f}_{\text {ck }}$ and the longitudinal reinforcement ratio $\boldsymbol{\rho}_{\mathbf{l}}$ in the estimation of the shear capacity. However, unlike the European standard which evaluates the effect of the reinforcement directly through $\boldsymbol{\rho}_{\mathbf{l}}$, the American standard considers the associated reinforcement strain (or stress) in the critical section at failure. According to (ACI Committee 318, 2014), it is not the longitudinal reinforcement ratio per se that governs the shear strength but the ratio $\mathrm{M} / \rho \mathrm{Vd}$. When adopting the ratio between the 
moment and shear at the section, the shear strength was related to the strain demand in the longitudinal reinforcement. (Khaja and Sherwood, 2013) also confirmed this by showing that the increase of $\rho_{\mathrm{l}}$ with the simultaneous increase of $\mathrm{a} / \mathrm{d}$ in order to make the ratio $\mathrm{M} / \rho \mathrm{Vd}$ constant will lead to shear failure stresses that are also constant (with $(\mathrm{a} / \mathrm{d}) / \rho=\mathrm{M} / \rho \mathrm{Vd})$. Note that (ACI Committee 318, 2014) does not consider both the influence of size effect and aggregate size on shear strength. For normal weight concrete $(\lambda=1)$, the shear strength is calculated as $\left(\mathrm{f}_{\mathrm{ck}}\right.$ in $\left.\mathrm{MPa}\right)$ :

$$
\mathrm{V}_{\mathrm{ACI}}=\left(0.16 \sqrt{\mathrm{f}_{\mathrm{ck}}}+17 \rho_{\mathrm{l}} \frac{\mathrm{Vd}_{\mathrm{l}}}{\mathrm{M}}\right) \mathrm{b}_{\mathrm{w}} \mathrm{d}_{\mathrm{l}} \leq 0.29 \sqrt{\mathrm{f}_{\mathrm{ck}}} \mathrm{b}_{\mathrm{w}} \mathrm{d}_{\mathrm{l}}
$$

Equation 5 is a semi-empirical formula recommended by (ACI-ASCE Committee 326, 1962) and developed by (Bresler and MacGregor, 1967) based on experimental results of 194 beams. The quantity Vd/M in Equation 5 cannot exceed one. In addition, the $17 \rho_{\mathrm{l}}(\mathrm{Vd} / \mathrm{M})$ term is generally negligible in case of practical designs according to (Bresler and Cordelis, 1963). (ACI Committee 318, 2014) also provides a simplified formula (Equation 6) used by most engineers that do not consider the effect of longitudinal reinforcement.

$$
\mathrm{V}_{\mathrm{ACI} \_ \text {simplified }}=0.17 \sqrt{\mathrm{f}_{\mathrm{ck}}} \mathrm{b}_{\mathrm{w}} \mathrm{d}_{\mathrm{l}}
$$

\subsection{MCFT based models: Fib Model Code 2010 and CSA A23.3}

Several shear design codes including (Fib Model Code 2010, 2012), (CSA Committee A23.3, 2004) or (AASHTO, 2004) derive from the Modified Compression Field Theory (MCFT) of (Vecchio and Collins, 1986). The concrete compressive strength, longitudinal reinforcement quantity, size effect and aggregate size are all taken into account by these models, unlike (CEN, 2005) which omits the aggregates size or (ACI Committee 318, 2014) which omits both the aggregates size and the size effect. In the MCFT approach, the failure shear stress $v_{\text {MCFT }}$ (Equation 7) is determined through a factor $\beta$ which characterizes the competence of the cracked concrete to transfer the shear stress by aggregates interlocking. The higher the value of $\beta$, the higher the aggregate interlock capacity. 


$$
v_{\mathrm{MCFT}}=\frac{\mathrm{V}_{\mathrm{MCFT}}}{\mathrm{b}_{\mathrm{w}} \times \mathrm{d}}=\beta \times \sqrt{\mathrm{f}_{\mathrm{c}}} \leq 0.25 \text { with } \sqrt{\mathrm{f}_{\mathrm{c}}} \leq 8 \mathrm{MPa} \quad\left[\mathrm{f}_{\mathrm{c}} \text { in MPa }\right]
$$

The MCFT allows to find the value of $\beta$ through the resolution of the equations it provides (Vecchio and Collins, 1986). However, solving these equations is a very time consuming effort. They require either to use tabular formats, or to perform iterations, and thus to have an appropriate computer program. In addition, many engineers prefer simple equations to tabular formats because they are more convenient for spreadsheet calculations. A simplified approach to MCFT utilizing continuous functions for shear capacity has therefore been developed by (Bentz et al., 2006), (Bentz and Collins., 2006) in which a simplified expression (Equation 8) was given for find the value $\beta$.

$$
\beta=\frac{0.40}{\left(1+1500 \varepsilon_{\mathrm{x}}\right)} \times \frac{1300}{\left(1000+\mathrm{s}_{\mathrm{xe}}\right)}=(\text { strain effect term }) \times(\text { size effect term })
$$

In this simplified theory (SMCFT-Simplified Modified Compression Field Theory), the estimation of the factor $\beta$ is founded on the fact that the crack width $w$ is equal to the product of the mean strain normal to the crack $\varepsilon$ and the cracks spacing $S$ in the normal direction $(w=\varepsilon \times s)$. It is known that aggregates interlocking capacity is intrinsically related to the width of the crack, the wider the crack, and the less effective the mechanism. However, the width of the cracks increases with the crack spacing and the longitudinal strain in the member (Walraven, 1981). Consequently, the shear capacity will decrease with all actions increasing the longitudinal strain or crack spacing as wider cracks will occur. Higher values of the longitudinal strain can be obtained, for example, by applying a tension axial load to the element, by decreasing the amount of the reinforcements or use reinforcements with low Young modulus, by increasing the ratio $\mathrm{M} / \mathrm{V}$ at the section. At the opposite, the application of an axial compression load for example will reduce the cracks formation and thus increases the shear capacity. All these actions are known as "strain effect". The size effect phenomenon is also taken into account through a "size effect" term. If the size effect is now an 
established experimental fact, its explanation is a complex problem in structures involving different approaches. The approach based on the fracture mechanics allows explaining the phenomenon. However, according to the MCFT, the size effect is caused by a reduction in the crack lips capacity to adequately transmit the shear forces through aggregates interlocking, due to crack opening. (Shioya et al., 1990) showed that the longitudinal cracks spacing at the mid-depth of RC beams and slabs not containing shear reinforcement tends to be about one-half of effective depth d, irrespective of the value of $d$. Consequently, if the depth increases, the crack spacing at mid-depth will increase and simultaneously the width of the cracks linked to the crack spacing will also increase. The parameter $\beta$ in the SMCFT is therefore estimated as the product of a "strain effect term" and a "size effect term". (Lubell et al., 2009) work showed that adopt an approach by considering the effects on the shear strength of size effects and strain effects as independent effects was a conceivable simplification. $s_{\mathrm{xe}}$ in the expression of $\beta$ is an "equivalent crack spacing factor" as defined in Equation 9. The longitudinal strain at the mid-depth of the member $\varepsilon_{\mathrm{x}}$ is calculated as defined in Equation 10 for sections for sections without prestressing and without axial forces.

$$
\begin{gathered}
s_{x e}=\frac{35 s_{x}}{\left(16+a_{g}\right)} \geq 0.85 s_{x} \\
\varepsilon_{x}=v_{M C F T} \times \frac{1+\frac{M}{V d}}{2 E_{s} \rho}=\left(\frac{\frac{M}{d}+V}{2 E_{s} \times A_{s}}\right)
\end{gathered}
$$

The crack spacing parameter $\mathrm{s}_{\mathrm{x}}$ can typically be taken as $0.9 \mathrm{~d}$ and $\mathrm{a}_{\mathrm{g}}$ the maximum aggregate size. $\mathrm{M}$ is the bending moment in the control section and $\mathrm{V}$ the corresponding shear force. $A_{s}$ is the crosssectional area of the longitudinal reinforcements and $\mathrm{E}_{\mathrm{s}}$ their Young modulus.

a. Fib Model Code 2010: LoA I and LoA II

This code is based on comprehensible physicomechanical models and represents a significant advance compared to empirical methods. The code (Fib Model Code 2010, 2012) contains four levels of shear strength approximation (LoA I to LoA IV) (Muttoni and Fernàndez, 
2012) consisting in addressing a computation by increasing the level of complexity leading to more precise results. Consequently, results closer to reality should be obtained for a higher LoA. The LoA I and LoA II have been analyzed in this study. The LoA II of the (Fib Model Code 2010, 2012) corresponds to the SMCFT. The shear capacity for a structural member not containing shear reinforcement is calculated as indicated in Equation $\mathbf{1 1}$ where $\mathrm{k}_{\mathrm{v}}$ is a parameter with the same physical sense as $\beta$ that is different depending on the level of approximation (LoA). Confronted to the LoA I, the LoA II gives a more precise value of the parameter $\mathrm{k}_{\mathrm{v}}$. In the LoA $\mathrm{I}, \mathrm{s}_{\mathrm{x} e}$ is assumed by simplification to be equal to 1.25 (maximum aggregate size $>9.6 \mathrm{~mm}$ ) and the longitudinal strain is assumed to be half the yield strain of the reinforcements which leads to $\varepsilon_{\mathrm{x}}=0.00125$ for reinforcements with $\mathrm{f}_{\mathrm{yk}}=500 \mathrm{MPa}$ and $\mathrm{E}_{\mathrm{s}}=200 \mathrm{GPa}$.

$$
\begin{gathered}
\mathrm{V}_{\text {Model Code }}=\mathrm{k}_{\mathrm{v}} \times \frac{\sqrt{\mathrm{f}_{\mathrm{ck}}}}{\gamma_{\mathrm{c}}} \times \mathrm{b}_{\mathrm{w}} \times \mathrm{d} \\
\mathrm{k}_{\mathrm{v}}(\text { LoA I })=\frac{180}{(1000+1.25 \mathrm{~d})} \\
\mathrm{k}_{\mathrm{v}}(\text { LoA II })=\beta=\frac{0.40}{\left(1+1500 \varepsilon_{\mathrm{x}}\right)} \times \frac{1300}{\left(1000+\mathrm{s}_{\mathrm{xe}}\right)}
\end{gathered}
$$

Note that according to fib-Model Code 2010, arching action is also accounted assuming that the contribution of point loads applied within a distance of $d \leq a_{v} \leq 2 d$ from the face of the support to the design shear force $V_{\mathrm{Ed}}$ may be reduced by the factor $\beta_{\text {Model Code }}=\beta_{\mathrm{EC} 2}=\mathrm{a}_{\mathrm{v}} / 2 \mathrm{~d}$.

\section{b. CSA A23.3 model}

As the (Fib Model Code 2010, 2012), the Canadian standard (CSA Committee A23.3, 2004) is also a Simplified Modified Compression Field Theory (SMCFT) based model and is equivalent to the LoA II. The shear capacity is therefore given by:

$$
\mathrm{V}_{\mathrm{CSA}}=\frac{0.40}{\left(1+1500 \varepsilon_{\mathrm{x}}\right)} \times \frac{1300}{\left(1000+\mathrm{s}_{\mathrm{xe}}\right)} \times \frac{\sqrt{\mathrm{f}_{\mathrm{ck}}}}{\gamma_{\mathrm{c}}} \times \mathrm{b}_{\mathrm{w}} \times \mathrm{d}
$$




\subsection{Critical Shear Crack Theory (CSCT)}

As the (Fib Model Code 2010, 2012), the CSCT introduced and developed by (Muttoni and Schwartz, 1991), (Muttoni, 2003a), (Muttoni, 2003b), (Muttoni and Ruiz, 2008) also derives from mechanical models which enable a physical understanding of tests results. The proposed theory also considers the influence of many shear governing parameters (concrete compressive strength, longitudinal reinforcement quantity, size effect and aggregate size) and has been introduced into the Swiss code for structural concrete (SIA 262, 2003) after reasonable simplifications.

According to CSCT, the shear capacity of members not containing shear reinforcement is governed by the width and the roughness of the critical shear crack. The critical shear crack theory reflects this dependency as expressed in Equation 15 where w is the critical shear crack width, and $\mathrm{a}_{\mathrm{g}}$ refers to the maximum aggregate size which considers the roughness of the crack lips.

$$
\frac{\mathrm{V}_{\mathrm{CSCT}}}{\mathrm{b}_{\mathrm{w}} \mathrm{d}}=\sqrt{\mathrm{f}_{\mathrm{c}}} \times \mathrm{f}\left(\mathrm{w}, \mathrm{a}_{\mathrm{g}}\right) \quad[\mathrm{MPa}, \mathrm{mm}]
$$

The CSCT assumes that the critical crack width $\mathrm{w}$ is proportional to the product of the longitudinal strain $\varepsilon$ in the control section (the control depth is located at a distance $0.6 \mathrm{~d}$ from the compression face) times the effective depth of element $d$. On the basis of these assumptions, the shear strength for elements not containing shear reinforcement is given by Equation 17.

$$
\begin{aligned}
& \mathrm{w} \propto \varepsilon \times \mathrm{d} \\
& \frac{\mathrm{V}_{\mathrm{CSCT}}}{\mathrm{b}_{\mathrm{w}} \mathrm{d} \sqrt{\mathrm{f}_{\mathrm{c}}}}=\frac{1 / 3}{1+120 \frac{\varepsilon \times \mathrm{d}}{16+\mathrm{a}_{\mathrm{g}}}}
\end{aligned}
$$

The longitudinal strain $\varepsilon$ in the control section can be approximated using the linear elasticity theory, assuming that the Navier-Bernoulli hypothesis according to which the plane sections remain plane after deformation is verified (the concrete tensile strength is neglected). For sections not 
subjected to axial loads, the strain in the control depth can be estimated by using the bending moment $\mathrm{M}$ in the control section (Equation 18). The compression zone depth $\mathrm{x}$ is calculated by Equation 19 in which $E_{c}$ refers to the Young modulus of concrete.

$$
\begin{gathered}
\varepsilon=\frac{M}{d \times \rho \times E_{s} \times\left(d-\frac{x}{3}\right)} \times \frac{0.6 d-x}{d-x} \\
x=d \times \rho \times \frac{E_{s}}{E_{c}} \times\left(\sqrt{1+\frac{2 E_{c}}{\rho E_{s}}}-1\right)
\end{gathered}
$$

Note that the (SIA 262, 2003) model is just a simplified design method based on the CSCT shear capacity expression (Equation 17). Some reasonable hypotheses are assumed (Muttoni and Ruiz, 2008). First, it is assumed to calculate $\varepsilon$ that the depth of the compression zone $\mathrm{x}$ is equal to $0.35 \mathrm{~d}$ (which is a reasonable value accounting for various reinforcement ratios and concrete strengths), thus:

$$
\varepsilon=\varepsilon_{\mathrm{s}} \times \frac{0.6 \mathrm{~d}-\mathrm{x}}{\mathrm{d}-\mathrm{x}} \cong 0.41 \times \varepsilon_{\mathrm{s}}
$$

Then the reinforcement strain $\varepsilon_{\mathrm{s}}$ is assumed proportional to the bending moment $\mathrm{M}_{\mathrm{Ed}}$. At yielding $\left(M_{E d}=M_{R d}\right)$, its value is $\varepsilon_{s}=f_{y d} / E_{s}$ with $f_{y d}=f_{y k} / \gamma_{s}$ the design strength of the reinforcement. At last, the flexural strength can be estimated according to the theory of plasticity as $\mathrm{M}_{\mathrm{Rd}}=$ $\rho d^{2} f_{y d}\left(1-\rho f_{y d} /\left(2 / f_{c d}\right)\right)$ with $f_{c d}=f_{c k} / \gamma_{c}$ the design concrete compressive strength. Considering these assumptions, the CSCT expression leads to the simplified expression below for (SIA 262, 2003).

$$
\frac{\mathrm{V}_{\text {SIA }}}{b_{\mathrm{w}} \mathrm{d} \sqrt{\mathrm{f}_{\mathrm{ck}}}}=\frac{0.3 / \gamma_{\mathrm{c}}}{1+\frac{50}{16+\mathrm{a}_{\mathrm{g}}} \times \frac{\mathrm{f}_{\mathrm{yk}}}{\gamma_{\mathrm{s}} \mathrm{E}_{\mathrm{s}}} \mathrm{d} \frac{\mathrm{M}_{\mathrm{Ed}}}{\mathrm{M}_{\mathrm{Rd}}}}
$$




\section{Experimental program}

\subsection{Thick slabs}

To investigate the RC slabs behaviour under shear loading, an experimental campaign consisted in testing eleven full-scale thick slabs without stirrups, with various thicknesses of $30 \mathrm{~cm}$, $35 \mathrm{~cm}$ and $40 \mathrm{~cm}$ (Nana et al., 2017). It is important to note that according to Eurocode 2, section 9.3 (CEN, 2005), thick slabs are those where the depth $\mathrm{h}$ is higher than one fifth of the span and Euler-Bernoully theory is not valid for these configurations of slabs. The term "thick slabs" is used here to highlight the fact that these slabs used in the nuclear power plant are thicker than those used in the standard buildings. To study the shear capacity, the slabs are subjected to a concentrated load. The shear force is favored with respect to the bending moment by applying the load near a support. At the interface between the slab and the supports, a layer of mortar was placed to ensure regular contact and consistency of the support. Regarding the boundary conditions, the slabs are simply supported on their four sides (Figure 1). The reinforcements are designed so that the failure does not occur by bending. It should be noted that the reinforcement's diameter is modified while their number is kept constant. The experimental campaign consisted of one slab (S6) of dimensions 4 $\mathrm{m} \times 2.6 \mathrm{~m} \times 0.35 \mathrm{~m}$, another (S7) of dimensions $4 \mathrm{~m} \times 2.6 \mathrm{~m} \times 0.40 \mathrm{~m}$ and the nine remaining slabs of dimensions $4 \mathrm{~m} \times 2.6 \mathrm{~m} \times 0.3 \mathrm{~m}$. The mechanical loading system consists of a hydraulic cylinder of 200-ton capacity and the loading is applied via a rectangular plate, the dimensions of which vary according to the slabs tested. The loading application is carried out with a quasi-static speed until the slab failure. The slabs concrete properties are given in Table $\mathbf{3}$. The concrete used to design the slabs was a ready-mixed concrete from a local supplier of VICAT concrete. The maximum aggregate size was $11.2 \mathrm{~mm}$ (except for the slab S2B with $20 \mathrm{~mm}$ of the maximum aggregate size). The concrete characterization tests are cylindrical specimens measuring $11 \times 22 \mathrm{~cm}$ carried out on the day that slab testing was performed. The specimens were placed in a humid chamber regulated in moisture and temperature. The composition of the concretes made is reported in Table 2 
Table 2 : Concrete composition used for thick slabs

\begin{tabular}{|ll|ll|}
\hline Designation: & BPS NF EN 2061/CN & Certification : & NF \\
\hline Exhibition class: & X0 (F) & Effective Water/ Binder equivalent: & 0.8 \\
\hline Consistency: & S3 & Maximum aggregate size: & D11.2 \\
\hline Characteristic resistance: & C20/25 & Dosage (Cement+Ecocem): & $145 \mathrm{~kg}$ \\
\hline Type and class of cement: & CEM II/A-LL 42,5 R CE NF VMO VICA & Class Chlorides: & $\mathrm{Cl} 0.40$ \\
\hline Adjuvant type: & PRE1 0.35\% & & \\
\hline
\end{tabular}
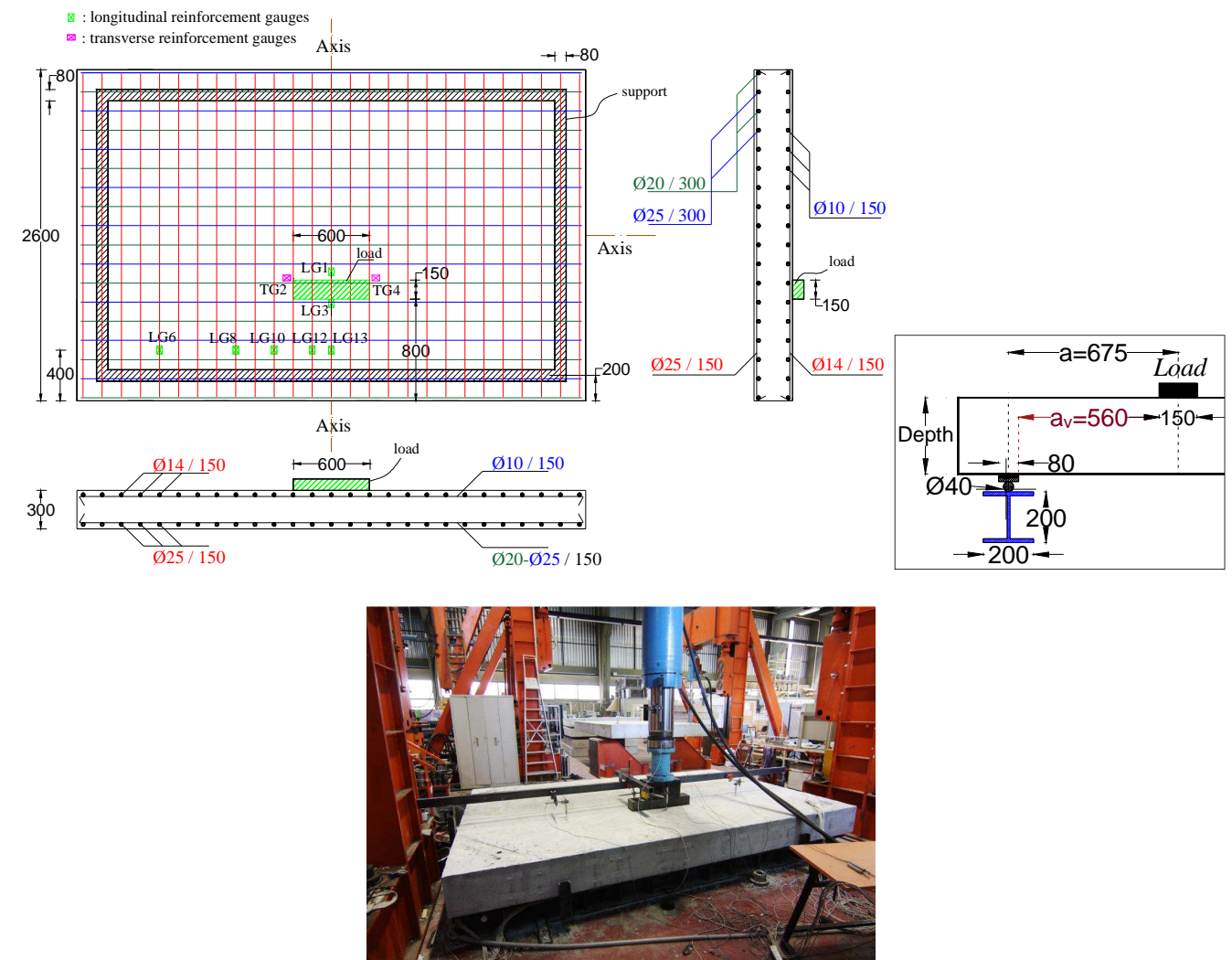

Figure 1: Reinforcement layout and test setup of thick slabs

The slabs are grouped by series. In each series, we analyze the effect of a given shear parameter. In Series I (S2, S8) the effect of concrete compressive strength, in Series II (S2, S6 and S7) the effect of $\mathrm{a}_{\mathrm{v}} / \mathrm{d}$ ratio, in Series III (S1, S4, and S5) the effect of longitudinal reinforcement ratio, in Series IV (S1-S3) the transverse reinforcement ratio, in Series V (S2, S2B) the concrete maximum aggregate size and finally in Series VI (S2, S9, S10) the loading plate length. 
Table 3 : Properties of thick slabs

\begin{tabular}{|c|c|c|c|c|c|c|c|c|c|c|}
\hline Series & Slabs & $\begin{array}{c}\mathbf{\rho l} \\
(\%)\end{array}$ & $\begin{array}{c}\text { pt } \\
(\%)\end{array}$ & $\begin{array}{c}\mathbf{d}_{\mathbf{l}} \\
{[\mathrm{mm}]}\end{array}$ & $\begin{array}{c}\mathbf{d}_{\mathrm{t}} \\
{[\mathrm{mm}]}\end{array}$ & $\begin{array}{c}\mathbf{a}_{\mathrm{v}} \\
{[\mathrm{mm}]}\end{array}$ & $\mathbf{a}_{v} / \mathbf{d}_{1}$ & $\begin{array}{c}\text { Concrete } \\
\text { class } \\
\text { [MPa] }\end{array}$ & $\begin{array}{c}\text { Maximum } \\
\text { aggregate size } \\
{[\mathrm{mm}]}\end{array}$ & $\begin{array}{c}\text { Loading } \\
\text { plate length } \\
{[\mathrm{mm}]}\end{array}$ \\
\hline \multirow{2}{*}{ I } & S2 & 1.223 & 1.106 & 267.5 & 242.5 & 560 & 2.1 & $\mathrm{C} 20 / 25$ & 11.2 & $600 \times 150$ \\
\hline & S8 & 1.223 & 1.106 & 267.5 & 242.5 & 560 & 2.1 & $\mathrm{C} 40 / 50$ & 11.2 & $600 \times 150$ \\
\hline \multirow{3}{*}{ II } & S2 & 1.223 & 1.106 & 267.5 & 242.5 & 560 & 2.1 & $\mathrm{C} 20 / 25$ & 11.2 & $600 \times 150$ \\
\hline & S6 & 1.030 & 0.917 & 317.5 & 292.5 & 560 & 1.8 & C20/25 & 11.2 & $600 \times 150$ \\
\hline & S7 & 0.890 & 0.783 & 367.5 & 342.5 & 560 & 1.5 & C20/25 & 11.2 & $600 \times 150$ \\
\hline \multirow{3}{*}{ III } & S1 & 1.223 & 0.854 & 267.5 & 245.0 & 560 & 2.1 & $\mathrm{C} 20 / 25$ & 11.2 & $600 \times 150$ \\
\hline & S4 & 1.003 & 0.854 & 267.5 & 245.0 & 560 & 2.1 & C20/25 & 11.2 & $600 \times 150$ \\
\hline & S5 & 1.551 & 0.837 & 270.0 & 250.0 & 560 & 2.1 & $\mathrm{C} 20 / 25$ & 11.2 & $600 \times 150$ \\
\hline \multirow{3}{*}{ IV } & S1 & 1.223 & 0.854 & 267.5 & 245.0 & 560 & 2.1 & $\mathrm{C} 20 / 25$ & 11.2 & $600 \times 150$ \\
\hline & S2 & 1.223 & 1.106 & 267.5 & 242.5 & 560 & 2.1 & $\mathrm{C} 20 / 25$ & 11.2 & $600 \times 150$ \\
\hline & S3 & 1.223 & 1.349 & 267.5 & 242.5 & 560 & 2.1 & C20/25 & 11.2 & $600 \times 150$ \\
\hline \multirow{2}{*}{ V } & S2 & 1.223 & 1.106 & 267.5 & 242.5 & 560 & 2.1 & $\mathrm{C} 20 / 25$ & 11.2 & $600 \times 150$ \\
\hline & $\mathrm{S} 2 \mathrm{~B}$ & 1.223 & 1.106 & 267.5 & 242.5 & 560 & 2.1 & C20/25 & 20.0 & $600 \times 150$ \\
\hline \multirow{3}{*}{ VI } & S2 & 1.223 & 1.106 & 267.5 & 242.5 & 560 & 2.1 & C20/25 & 11.2 & $600 \times 150$ \\
\hline & S9 & 1.167 & 1.056 & 267.5 & 242.5 & 560 & 2.1 & C20/25 & 11.2 & $700 \times 150$ \\
\hline & S10 & 1.117 & 1.010 & 267.5 & 242.5 & 560 & 2.1 & $\mathrm{C} 20 / 25$ & 11.2 & $800 \times 150$ \\
\hline
\end{tabular}

\subsection{Thin slabs}

Another shear experimental campaign was performed, this time on seven thin slabs of $10 \mathrm{~cm}$ also under a concentrated load located at the proximity of the support. The tests were carried out with a structure like a floor system in which a concrete floor slab was supported by the reinforced concrete beams (Bui et al., 2017). This other experimental campaign consisted of one slab (N1) measuring $2.9 \mathrm{~m} \times 2.9 \mathrm{~m} \times 0.1 \mathrm{~m}$ and six slabs $(\mathrm{N} 2, \mathrm{~N} 3, \mathrm{~N} 5, \mathrm{~N} 5 \mathrm{Bis}, \mathrm{N} 6, \mathrm{~N} 6 \mathrm{Bis})$ measuring $2.9 \mathrm{~m} \times 2.5$ $\mathrm{m} \times 0.1 \mathrm{~m}$. The slabs are grouped by series. In each series, we study the effect of a given slab configuration under shear loading. In Series A (N1 Vs N2) the effect of the boundary conditions with slab supported on two sides instead four sides, in Series B (N2 Vs N3) the effect of loading plate length, in Series C (N5, N5Bis Vs N6, N6Bis - N5, N6 Vs N5Bis, N6Bis) the effect of both loading plate length and boundary condition by applying a lateral restraint at the two extremities of 
the beam supports for N5Bis and N6Bis tests contrary to other tests where the beams are directly supported by the laboratory floor with a mortar layer placed at the interface. The reinforcement layout and the concrete properties of specimens are illustrated in Figure $\mathbf{2}$ and Table $\mathbf{5}$ respectively.

The specimens were cast using ready-mixed concrete of C25/30. A maximum aggregate size of 20 $\mathrm{mm}$ was used. The composition of the concretes made is reported in Table 4.

Supprimé: Figure 2

Mis en forme : Police : $12 \mathrm{pt}$, Gras

Supprimé: Table 5

Mis en forme : Police : $12 \mathrm{pt}$, Gras

Mis en forme : Police :12 pt, Gras

Supprimé: Table 4

Table 4: Concrete composition used for thin slabs

\begin{tabular}{|ll|ll|}
\hline Designation: & BPS NF EN 2061/CN & Certification : & NF \\
\hline Exhibition class: & XC1 (F) & Effective Water/ Binder equivalent: & 0.65 \\
\hline Consistency: & S3 & Maximum aggregate size: & D20 \\
\hline Characteristic resistance: & C 25/30 & Dosage (Cement+Ecocem): & $260 \mathrm{~kg}$ \\
\hline Type and class of cement: & CEM II/A-LL 42,5 R CE NF VMO VICA & Class Chlorides: & CI 0.40 \\
\hline Adjuvant type: & SPHR3 0.40\% PRE2 0.20\% & & \\
\hline
\end{tabular}

Table 5: Properties of thin slabs

\begin{tabular}{|c|c|c|c|c|c|c|c|c|c|c|}
\hline Series & Slabs & $\begin{array}{l}\text { Number } \\
\text { supports }\end{array}$ & $\begin{array}{c}\text { pl } \\
(\%)\end{array}$ & $\begin{array}{c}\rho t \\
(\%)\end{array}$ & $\begin{array}{c}\mathbf{d}_{\mathbf{l}} \\
{[\mathrm{mm}]}\end{array}$ & $\begin{array}{c}\mathbf{a}_{\mathbf{v}} \\
{[\mathrm{mm}]}\end{array}$ & $a_{v} / d_{l}$ & $\begin{array}{c}\text { Concrete } \\
\text { class } \\
\text { [MPa] }\end{array}$ & $\begin{array}{c}\text { Maximum } \\
\text { aggregate } \\
\text { size } \\
{[\mathrm{mm}]}\end{array}$ & $\begin{array}{c}\text { Loading } \\
\text { plate } \\
\text { length } \\
\text { [mm] }\end{array}$ \\
\hline \multirow{2}{*}{ A } & N1 & 4 & 0.770 & 1.039 & 85 & 170 & 2.0 & $\mathrm{C} 25 / 30$ & 20.0 & $1000 \times 200$ \\
\hline & $\mathrm{N} 2$ & 2 & 1.160 & 0.303 & 85 & 170 & 2.0 & $\mathrm{C} 25 / 30$ & 20.0 & $1000 \times 200$ \\
\hline \multirow{2}{*}{ B } & $\mathrm{N} 2$ & 2 & 1.160 & 0.303 & 85 & 170 & 2.0 & $\mathrm{C} 25 / 30$ & 20.0 & $1000 \times 200$ \\
\hline & N3 & 2 & 1.160 & 0.182 & 85 & 170 & 2.0 & $\mathrm{C} 25 / 30$ & 20.0 & $400 \times 200$ \\
\hline \multirow{4}{*}{$\mathrm{C}$} & N5 & 2 & 1.000 & 0.406 & 85 & 170 & 2.0 & $\mathrm{C} 25 / 30$ & 20.0 & $1000 \times 200$ \\
\hline & N5Bis & 2 & 1.000 & 0.406 & 85 & 170 & 2.0 & $\mathrm{C} 25 / 30$ & 20.0 & $1000 \times 200$ \\
\hline & N6 & 2 & 1.010 & 0.406 & 85 & 170 & 2.0 & $\mathrm{C} 25 / 30$ & 20.0 & $400 \times 200$ \\
\hline & N6Bis & 2 & 1.010 & 0.406 & 85 & 170 & 2.0 & $\mathrm{C} 25 / 30$ & 20.0 & $400 \times 200$ \\
\hline
\end{tabular}



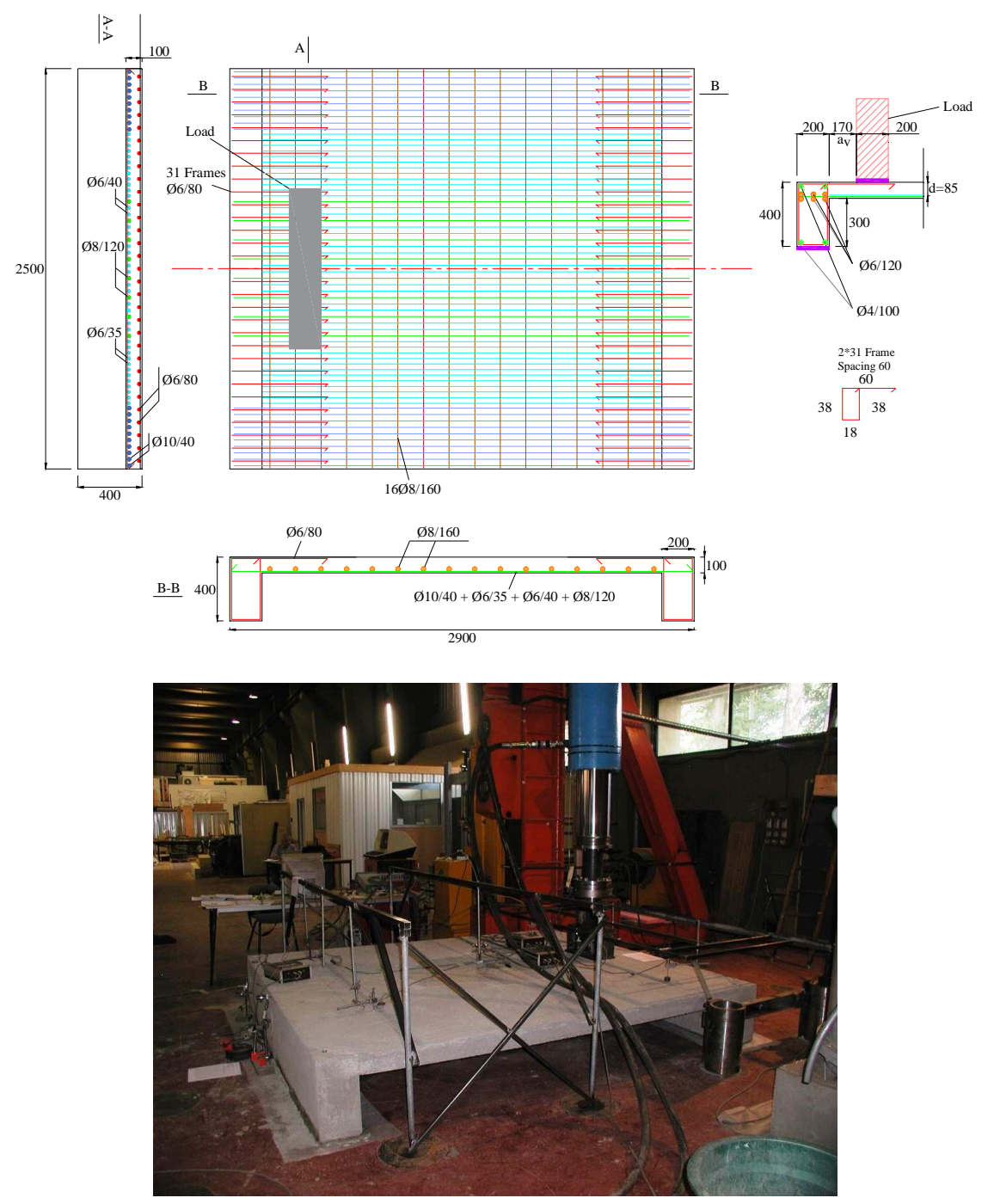

Figure 2: Reinforcement layout and test setup of thin slabs

\section{Experimental results}

\subsection{Failure modes}

The failure modes obtained for slabs are presented in Figure $\mathbf{3}$ and Figure $\mathbf{4}$ for thick slabs and thin slabs respectively. The first overload fracture is observed at the proximity of the support what is apparent to a one-way shear (shear failure). This cracking line whose length is equivalent to
Supprimé: Figure 3

Supprimé: Figure 4

Mis en forme : Police :12 pt, Gras

Mis en forme : Police :12 pt, Gras 
the shear effective width $b_{\text {eff }}$ has a relatively larger opening than that of the other cracking lines observed. The mechanism of slabs shear failure corresponds to the appearance of this macro cracking.

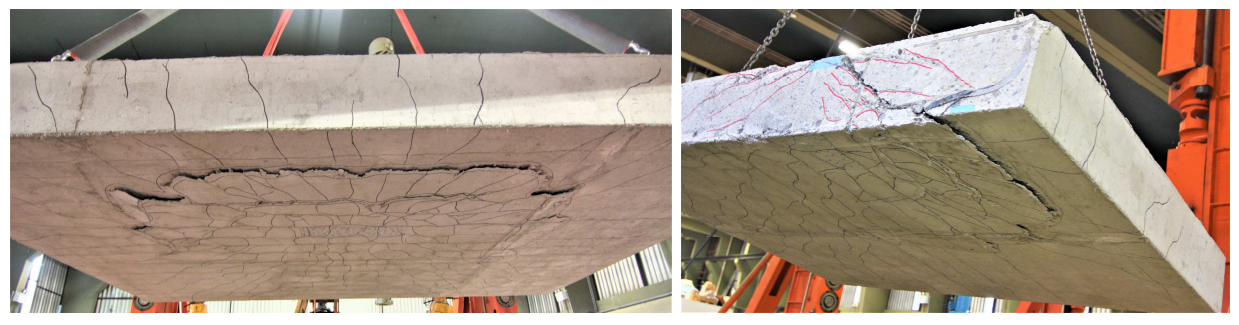

Figure 3 : Thick slab failure mode: a) bottom face; b) saw-cut
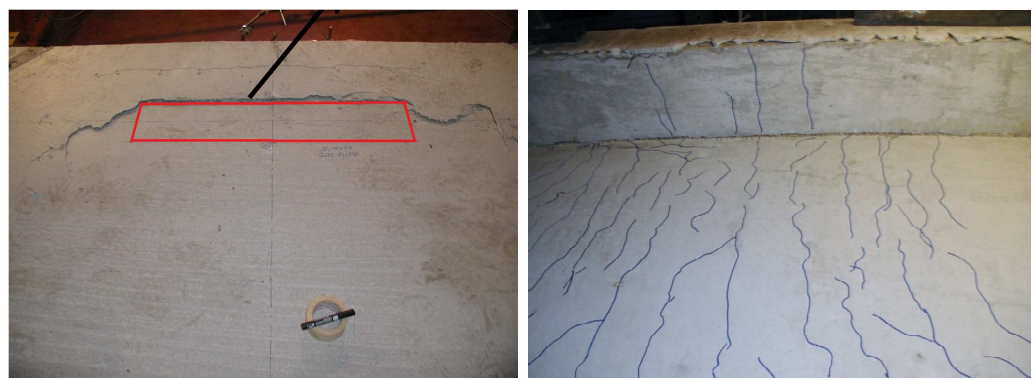

Figure 4: Thin slab failure mode: a) top face; b) bottom face

\subsection{Shear capacities}

For slabs under concentrated load, the shear strength should not be calculated over the entire width as in the case of beams but over the effective width $b_{\text {eff. }}$ The French code (FD P 18-717, 2013) and the (Fib Model Code 2010, 2012) adopt different approaches to calculate the effective width as shown in Figure 5. In the French approach, the hypothesis of a $45^{\circ}$ load diffusion, resulting from the contour of the load zone in the direction of the supports $\left(b_{\mathrm{eff}, 2}\right)$ is assumed Mis en forme : Police : $12 \mathrm{pt}$ Supprimé: Figure 5

(Figure 5a). Some studies showed that the shear strength determined using the French effective width recommendation has a good capacity to predict the experimental shear capacities (Regan and

Rezai-Jorabi, 1988), (Lantsoght et al., 2012), (Belletti et al., 2014). In the present study, to 
facilitate comparisons between the design codes, the same effective width $\left(b_{\text {eff }, 2}\right)$ of the French approach was used. Note that the values of be $\mathrm{ff}_{2}$ according to (FD P 18-717, 2013) and $b_{\mathrm{eff}, 3}$ for the (Fib Model Code 2010, 2012) are very close as given in Table 6 and don't affect the results significantly.

Mis en forme : Police :12 pt, Gras, Anglais (Royaume-Uni)

Supprimé: Table 6
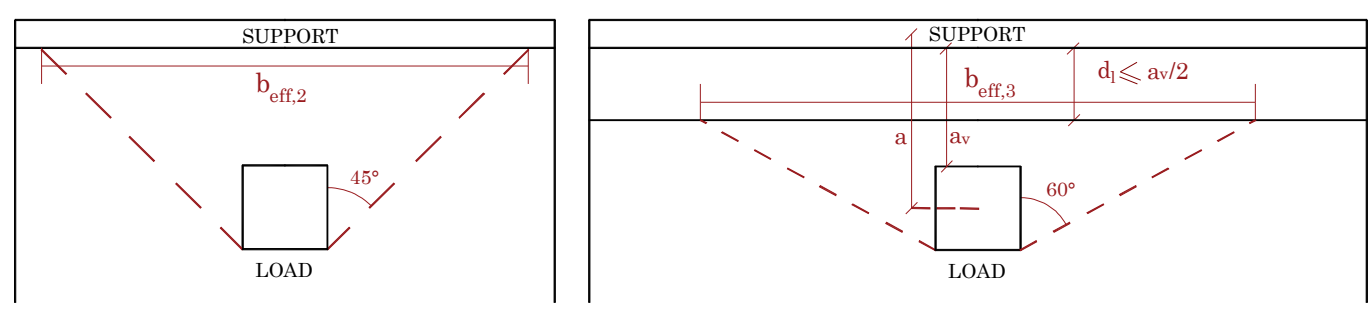

Figure 5: Determination of the effective width beff; (a) French approach; (b) fib-Model Code 2010 approach

The peak loads values obtained from the experiments $\mathrm{P}_{\mathrm{u}}$ and the corresponding ultimate shear loads $V_{\exp }$ are given in Table 6. For each slab, the ultimate shear loads $V_{\text {exp }}$ is calculated from the peak loads $\mathrm{P}_{\mathrm{u}}$ through a model using the Navier method with linear displacement hypothesis (Timoshenko and Woinowsky-Krieger, 1959). It should be noted that the slabs self-weight is not taken into account in the determination of the ultimate shear load $V_{\text {exp }}$, its effect is negligible compared with that of the localized load causing the failure.

Table 6: Peak loads obtained for slabs

\begin{tabular}{|c|c|c|c|c|c|c|c|c|c|c|}
\hline \multirow[t]{2}{*}{ Slabs } & \multirow[t]{2}{*}{$a_{v} / d_{l}$} & pl & $\rho t$ & \multirow[t]{2}{*}{$\begin{array}{l}\mathbf{f}_{\mathrm{cm}, \text { meas }} \\
\text { [MPa] }\end{array}$} & \multirow{2}{*}{$\begin{array}{c}\mathbf{b}_{\text {eff,2 }} \\
{[\mathrm{mm}]}\end{array}$} & \multirow{2}{*}{$\begin{array}{c}\mathbf{b}_{\text {eff,3 }} \\
{[\mathrm{mm}]}\end{array}$} & \multirow{2}{*}{$\begin{array}{r}\mathbf{P}_{\mathbf{u}} \\
\\
{[\mathrm{kN}]}\end{array}$} & \multirow{2}{*}{ Failure mode } & \multirow{2}{*}{$\begin{array}{l}\mathbf{V}_{\text {exp }} \\
{[\mathrm{kN}]}\end{array}$} & \multirow[t]{2}{*}{$\mathbf{V}_{\text {exp }} / \sqrt{\mathbf{f}_{\text {cm }}}$} \\
\hline & & {$[\%]$} & {$[\%]$} & & & & & & & \\
\hline S1 & 2.1 & 1.223 & 0.854 & 24.1 & 2100 & 2270 & 1111 & Shear & 680 & 139 \\
\hline $\mathrm{S} 2$ & 2.1 & 1.223 & 1.106 & 30.9 & 2100 & 2270 & 1220 & Shear & 747 & 134 \\
\hline $\mathrm{S} 2 \mathrm{~B}$ & 2.1 & 1.223 & 1.106 & 30.5 & 2100 & 2270 & 1353 & Shear & 828 & 150 \\
\hline $\mathrm{S} 3$ & 2.1 & 1.223 & 1.349 & 18.8 & 2100 & 2270 & 1032 & Shear & 632 & 146 \\
\hline S4 & 2.1 & 1.003 & 0.854 & 23.9 & 2100 & 2270 & 1050 & Shear & 643 & 132 \\
\hline S5 & 2.1 & 1.551 & 0.837 & 34.6 & 2100 & 2270 & 1257 & Shear & 769 & 131 \\
\hline S6 & 1.8 & 1.030 & 0.917 & 33.2 & 2100 & 2100 & 1427 & Shear & 888 & 154 \\
\hline
\end{tabular}




\begin{tabular}{ccccccccccc}
\hline S7 & 1.5 & 0.890 & 0.783 & 34.2 & 2100 & 2230 & 1796 & Shear & 1135 & 194 \\
S8 & 2.1 & 1.223 & 1.106 & 51.7 & 2100 & 2270 & 1632 & Shear & 999 & 139 \\
S9 & 2.1 & 1.167 & 1.056 & 30.4 & 2200 & 2370 & 1350 & Shear & 825 & 150 \\
S10 & 2.1 & 1.117 & 1.010 & 30.6 & 2300 & 2470 & 1221 & Shear & 745 & 135 \\
\hline N1 & 2.0 & 0.770 & 1.039 & 25.8 & 1740 & 1987 & 294 & Shear & 212 & 42 \\
N2 & 2.0 & 1.160 & 0.303 & 30.4 & 1740 & 1987 & 308 & Shear & 275 & 50 \\
N3 & 2.0 & 1.160 & 0.182 & 30.4 & 1140 & 1387 & 196 & Shear & 175 & 32 \\
N5 & 2.0 & 1.000 & 0.406 & 30.2 & 1740 & 1987 & 342 & Shear & 305 & 56 \\
N5Bis & 2.0 & 1.000 & 0.406 & 30.2 & 1740 & 1987 & 351 & Shear & 313 & 57 \\
N6 & 2.0 & 1.010 & 0.406 & 19.2 & 1140 & 1387 & 185 & Shear & 165 & 38 \\
N6Bis & 2.0 & 1.010 & 0.406 & 19.2 & 1140 & 1387 & 166 & Shear & 148 & 34 \\
\hline
\end{tabular}

\section{Experimental results Vs Analytical predictions}

The experimental results are compared to the Eurocode 2 (EC2), French (FNA), ACI 31814, Fib Model Code 2010 (MC) using level of approximation LoA I and LoA II and Critical Shear Crack Theory (CSCT) predictions models. The effective width according to French recommendation $b_{\text {eff }}$ is used instead of the entire width $b_{w}$. All the partial safety factors are set equal to $1\left(\gamma_{\mathrm{c}}=1\right)$ and the mean values of the concrete mechanical properties measured are used. The shear strength of slabs according to the fib Model Code LoA II, CSCT and ACI 318 (non-simplified expression) which are sensitive to the applied moment (with a lesser degree for ACI), are determined in a shear control section that must be specified. The bending moment and the shear force obtained at the control section are used for the calculations and predict shear failure in the region along the shear span in which the moment is higher. The control section is generally defined at a distance $d$ (the effective depth of the specimen) from the face of the load. This potentially critical section is admitted in our study. The reinforcement's Young modulus is assumed to be 210 GPa. 
The confrontation between the experimental results and the design models is shown in

Table 7 Table 8 . Table 9 and Table 10. The average (AVG) and standard deviation (STD) of the comparison between the experimental results and the design models are shown in Table 9 and Table 10. For the case of thick slabs, these results show that compared to Eurocode 2 and ACI 318-14, the French National Annex approach FNA $(\mathrm{AVG}=1.09, \mathrm{STD}=0.08)$ give predictions that are very close to experimental ones. The Eurocode 2 approach also give acceptable results as this code is reasonably predicting the shear capacities $(\mathrm{AVG}=1.22, \mathrm{STD}=0.09)$. However the ACI $318-14$ and ACI simplified give conservative results with $(\mathrm{AVG}=1.32, \mathrm{STD}=0.08)$ and $(\mathrm{AVG}=1.43, \mathrm{STD}=0.08)$ respectively, the results are underestimated in all experiments. The comparison of experimental results to the EC2, French approach, and ACI 318-04 predictions is illustrated in Figure 6 6 and the degree of conservatism illustrated in Figure 10a. In the case of thin slabs of $10 \mathrm{~cm}$, the same conclusions are drawn, in the sense that the closest predictions with the experimental results are obtained in the order with FNA (AVG=1.52, STD=0.17), Eurocode $2(\mathrm{AVG}=1.69, \mathrm{STD}=0.14)$ and ACI 318-14 (AVG=1.90, STD=0.15). However compared to prediction levels for thick slabs, for thinner $10 \mathrm{~cm}$ slabs, the predictions for all models seem more conservative. The comparison of experimental results with the predictions is illustrated in Figure $\mathbf{7}$ and the degree of conservatism illustrated in Figure 10b.

Concerning the Fib Model Code 2010 with LoA II approximation level (equivalent to CSA A23.3) and the Critical Shear Crack Theory CSCT, for the case of thick slabs, the results show that both models give excellent predictions with $(\mathrm{AVG}=1.06, \mathrm{STD}=0.11)$ and $(\mathrm{AVG}=1.04, \mathrm{STD}=0.08)$ respectively. In the case of thin slabs, the same conclusions are also drawn with Fib Model Code 2010 LoA II $(\mathrm{AVG}=1.29, \mathrm{STD}=0.15), \mathrm{CSCT}(\mathrm{AVG}=1.11, \mathrm{STD}=0.12)$. However, the predictions also seem a little more conservative. As Fib Model Code 2010 and CSCT models are physical (mechanical) based models contrary to others empirical codes and, given the very good accuracy of predictions, they could provide a unified approach to shear design for one way shear. The Model

\begin{tabular}{|c|}
\hline Supprimé: Table 7 \\
\hline Mis en forme : Police : $12 \mathrm{pt}$, Gras \\
\hline Supprimé: Table 10 \\
\hline Supprimé: Table 8 \\
\hline Supprimé: Table 9 \\
\hline Mis en forme : Police : $12 \mathrm{pt}$, Gras \\
\hline Mis en forme : Police :Gras \\
\hline Mis en forme : Police : $12 \mathrm{pt}$, Gras \\
\hline Mis en forme : Police :Gras \\
\hline Supprimé: Table 9 \\
\hline Mis en forme : Police : $12 \mathrm{pt}$, Gras \\
\hline Supprimé: Table 10 \\
\hline
\end{tabular}

Mis en forme : Police :12 pt, Gras Supprimé: Figure 6 Supprimé: Figure 10 Mis en forme : Police :Gras Mis en forme : Police :12 pt, Gras Supprimé: Figure 7 Mis en forme : Police :12 pt, Gras

Supprimé: Figure 10 
Code 2010 with the first level of approximation (LoA I) seems to be very conservative (AVG = $1.83, \mathrm{STD}=0.12$ for thick slabs and $\mathrm{AVG}=2.15, \mathrm{STD}=0.23$ for thin slabs $)$. This seems logical as the LoA I is suitable for pre-dimensioning of structural elements, where a conservative calculation method is acceptable. The comparison of test results to the Fib Model Code 2010 (LoA I and LoA II) and the CSCT predictions are illustrated in Figure 8. Figure 9 and Figure 10.

Table 7: Thick slabs: experimental results Vs predictions of EC2, French approach, ACI 318-14, Model Code 2010 (MC) and Critical Shear Crack Theory (CSCT).

\begin{tabular}{|c|c|c|c|c|c|c|c|c|c|}
\hline \multirow[t]{2}{*}{ Test } & \multicolumn{2}{|c|}{ Experiment } & \multicolumn{7}{|c|}{$\mathbf{V}$ with $\mathbf{f}_{\mathrm{cm} \text {,meas }}$} \\
\hline & $\mathbf{P}_{\mathbf{u}}$ & $\mathbf{V}_{\exp }$ & $\mathrm{V}_{\mathrm{EC} 2}$ & $V_{\text {France }}$ & $\mathrm{V}_{\mathrm{ACI}}$ & $\mathrm{V}_{\mathrm{ACI}, \text { simplified }}$ & $\mathrm{V}_{\mathrm{MC}-\mathrm{LOA} I}$ & $\mathrm{~V}_{\mathrm{MC}-\text { LoA II }}$ & $\mathrm{V}_{\mathrm{CSCT}}$ \\
\hline & {$[\mathrm{kN}]$} & {$[\mathrm{kN}]$} & {$[\mathrm{kN}]$} & {$[\mathrm{kN}]$} & {$[\mathrm{kN}]$} & {$[\mathrm{kN}]$} & {$[\mathbf{k N}]$} & {$[\mathrm{kN}]$} & {$[\mathrm{kN}]$} \\
\hline S1 & 1111 & 680 & 582 & 625 & 518 & 469 & 372 & 661 & 665 \\
\hline $\mathrm{S} 2$ & 1220 & 747 & 633 & 708 & 576 & 531 & 421 & 721 & 726 \\
\hline S2B & 1353 & 828 & 630 & 703 & 573 & 527 & 418 & 728 & 762 \\
\hline S3 & 1032 & 632 & 536 & 552 & 466 & 414 & 329 & 600 & 600 \\
\hline $\mathrm{S} 4$ & 1050 & 643 & 544 & 622 & 502 & 467 & 370 & 621 & 627 \\
\hline S5 & 1257 & 769 & 716 & 756 & 633 & 567 & 449 & 836 & 834 \\
\hline S6 & 1427 & 888 & 719 & 804 & 706 & 653 & 495 & 891 & 949 \\
\hline S7 & 1796 & 1135 & 833 & 931 & 828 & 767 & 557 & 930 & 1039 \\
\hline S8 & 1632 & 999 & 751 & 916 & 723 & 687 & 545 & 816 & 835 \\
\hline S9 & 1350 & 825 & 649 & 735 & 596 & 552 & 438 & 751 & 739 \\
\hline $\mathrm{S} 10$ & 1221 & 745 & 670 & 771 & 621 & 579 & 459 & 834 & 787 \\
\hline
\end{tabular}

Table 8: Thin slabs: experimental results Vs predictions of EC2, French approach, ACI 318-14, Model Code 2010 (MC) and Critical Shear Crack Theory (CSCT).

\begin{tabular}{|c|c|c|c|c|c|c|c|c|c|}
\hline \multirow[t]{2}{*}{ Test } & \multicolumn{2}{|c|}{ Experiment } & \multicolumn{7}{|c|}{$\mathbf{V}$ with $\mathbf{f}_{\mathrm{cm} \text {, meas }}$} \\
\hline & $\mathbf{P}_{\mathbf{u}}$ & $\mathbf{V}_{\text {exp }}$ & $\mathrm{V}_{\mathrm{EC} 2}$ & $V_{\text {France }}$ & $\mathrm{V}_{\mathrm{ACI}}$ & $\mathrm{V}_{\mathrm{ACI} \text {,simplfied }}$ & $\mathrm{V}_{\mathrm{MC}-\mathrm{LoA} I}$ & $\mathrm{~V}_{\text {MC-LoA II }}$ & $\mathrm{V}_{\mathrm{CSCT}}$ \\
\hline & {$[\mathrm{kN}]$} & {$[\mathrm{kN}]$} & {$[\mathrm{kN}]$} & {$[\mathrm{kN}]$} & {$[\mathrm{kN}]$} & {$[\mathrm{kN}]$} & {$[\mathrm{kN}]$} & {$[\mathrm{kN}]$} & {$[\mathrm{kN}]$} \\
\hline N1 & 294 & 212 & 139 & 173 & 124 & 128 & 122 & 194 & 231 \\
\hline
\end{tabular}




\begin{tabular}{ccc|c|c|c|c|c|c|c|}
\hline N2 & 308 & 275 & 167 & 188 & 150 & 139 & 133 & 239 & 255 \\
\cline { 7 - 11 } N3 & 196 & 175 & 111 & 123 & 99 & 91 & 87 & 134 & 171 \\
N5 & 342 & 305 & 166 & 187 & 150 & 138 & 132 & 217 & 252 \\
\cline { 7 - 11 } N5Bis & 351 & 313 & 166 & 187 & 150 & 138 & 132 & 215 & 251 \\
\cline { 7 - 11 } N6 & 185 & 165 & 94 & 98 & 81 & 72 & 69 & 114 & 137 \\
\cline { 7 - 11 } N6Bis & 166 & 148 & 94 & 98 & 81 & 72 & 69 & 119 & 138 \\
\hline
\end{tabular}

Table 9: Thick slabs: ratios between experimental results and models predictions.

\begin{tabular}{|c|c|c|c|c|c|c|c|c|c|}
\hline \multirow[t]{2}{*}{ Test } & \multicolumn{2}{|c|}{ Experiment } & \multirow{2}{*}{ 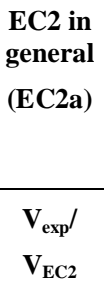 } & \multirow{2}{*}{$\begin{array}{c}\text { EC2 with } \\
\text { French } \\
\text { approach } \\
(\text { EC2b) } \\
V_{\text {exp }} / \\
V_{\text {France }}\end{array}$} & \multirow{2}{*}{$\begin{array}{c}\text { ACI } \\
318 \\
(\text { ACI } \\
\text { 318a) } \\
V_{\text {exp }} / \\
V_{\text {ACI }} \\
\end{array}$} & \multirow{2}{*}{$\begin{array}{c}\text { ACI } 318 \\
\text { Simplified } \\
\text { (ACI } \\
\text { 318b) } \\
V_{\text {exp }} / \\
\text { V }_{\text {ACI, simplified }}\end{array}$} & \multirow{2}{*}{$\begin{array}{c}\begin{array}{c}\text { Model } \\
\text { Code } \\
\text { (LoA I) }\end{array} \\
\text { (MC I) } \\
\mathbf{V}_{\text {exp }} / \\
\text { V }_{\text {MC-LoAI }}\end{array}$} & \multirow{2}{*}{$\begin{array}{c}\begin{array}{c}\text { Model } \\
\text { Code } \\
\text { (LoA II) } \\
\text { (MC II) }\end{array} \\
\text { Vexp }_{\text {exp }} \\
\text { V }_{\text {MC-LoAII }}\end{array}$} & \multirow{2}{*}{$\begin{array}{c}\text { Critical Shear } \\
\text { Crack Theory } \\
\text { (CSCT) }\end{array}$} \\
\hline & $\begin{array}{c}\mathbf{P}_{\mathbf{u}} \\
{[\mathbf{k N}]}\end{array}$ & $\begin{array}{c}\mathbf{V}_{\text {exp }} \\
{[\mathrm{kN}]}\end{array}$ & & & & & & & \\
\hline S1 & 1111 & 680 & 1.17 & 1.09 & 1.31 & 1.45 & 1.83 & 1.03 & 1.02 \\
\hline S2 & 1220 & 747 & 1.18 & 1.06 & 1.30 & 1.41 & 1.77 & 1.04 & 1.03 \\
\hline $\mathrm{S} 2 \mathrm{~B}$ & 1353 & 828 & 1.31 & 1.18 & 1.45 & 1.57 & 1.98 & 1.14 & 1.09 \\
\hline S3 & 1032 & 632 & 1.18 & 1.14 & 1.35 & 1.53 & 1.92 & 1.05 & 1.05 \\
\hline S4 & 1050 & 643 & 1.18 & 1.03 & 1.28 & 1.38 & 1.73 & 1.04 & 1.03 \\
\hline S5 & 1257 & 769 & 1.07 & 1.02 & 1.22 & 1.36 & 1.71 & 0.92 & 0.92 \\
\hline S6 & 1427 & 888 & 1.23 & 1.10 & 1.26 & 1.36 & 1.79 & 1.00 & 0.94 \\
\hline S7 & 1796 & 1135 & 1.36 & 1.22 & 1.37 & 1.48 & 2.04 & 1.22 & 1.09 \\
\hline S8 & 1632 & 999 & 1.33 & 1.09 & 1.38 & 1.45 & 1.83 & 1.22 & 1.20 \\
\hline S9 & 1350 & 825 & 1.27 & 1.12 & 1.38 & 1.50 & 1.88 & 1.10 & 1.12 \\
\hline $\mathrm{S} 10$ & 1221 & 745 & 1.11 & 0.97 & 1.20 & 1.29 & 1.62 & 0.89 & 0.95 \\
\hline & AVG & & 1.22 & 1.09 & 1.32 & 1.43 & 1.83 & 1.06 & 1.04 \\
\hline & STD & & 0.09 & 0.07 & 0.08 & 0.08 & 0.12 & 0.11 & 0.08 \\
\hline & Percent & & 1.09 & 1.00 & 1.21 & 1.33 & 1.67 & 0.91 & 0.93 \\
\hline
\end{tabular}

Table 10: Thin slabs: ratios between experimental results and models predictions.

\begin{tabular}{|c|c|c|c|c|c|c|c|c|}
\hline Test & Experiment & $\begin{array}{l}\mathrm{EC} 2 \text { in } \\
\text { general } \\
(\mathrm{EC} 2 \mathrm{a})\end{array}$ & $\begin{array}{c}\text { EC2 with } \\
\text { French } \\
\text { approach }\end{array}$ & $\begin{array}{c}\text { ACI } \\
318 \\
\text { (ACI }\end{array}$ & $\begin{array}{c}\text { ACI } 318 \\
\text { Simplified } \\
\text { (ACI }\end{array}$ & $\begin{array}{c}\text { Model } \\
\text { Code } \\
\text { (LoA I) }\end{array}$ & $\begin{array}{c}\text { Model } \\
\text { Code } \\
\text { (LoA II) }\end{array}$ & $\begin{array}{c}\text { Critical } \\
\text { Shear Crack } \\
\text { Theory }\end{array}$ \\
\hline
\end{tabular}




\begin{tabular}{|c|c|c|c|c|c|c|c|c|c|}
\hline & & & & (EC2b) & 318a) & 318b) & (MC I) & (MC II) & (CSCT) \\
\hline & $\mathbf{P}_{\mathbf{u}}$ & $\mathbf{V}_{\text {exp }}$ & $\mathbf{V}_{\text {exp }} /$ & $\mathbf{V}_{\text {exp }} /$ & $\mathbf{V}_{\text {exp }} /$ & $\mathbf{V}_{\text {exp }} /$ & $\mathbf{V}_{\text {exp }} /$ & $\mathbf{V}_{\text {exp }} /$ & $\mathbf{V}_{\text {exp }} /$ \\
\hline & {$[\mathrm{kN}]$} & {$[\mathrm{kN}]$} & $\mathbf{V}_{\mathrm{EC} 2}$ & $\mathbf{V}_{\text {France }}$ & $\mathbf{V}_{\mathrm{ACI}}$ & $\mathbf{V}_{\mathrm{ACI}, \text { simplified }}$ & $\mathbf{V}_{\text {MC-LoAI }}$ & $\mathbf{V}_{\text {MC-LoAII }}$ & $\mathbf{V}_{\mathrm{CSCT}}$ \\
\hline N1 & 294 & 212 & 1.52 & 1.23 & 1.70 & 1.66 & 1.73 & 1.09 & 0.92 \\
\hline $\mathrm{N} 2$ & 308 & 275 & 1.65 & 1.46 & 1.83 & 1.98 & 2.07 & 1.15 & 1.08 \\
\hline N3 & 196 & 175 & 1.58 & 1.42 & 1.77 & 1.92 & 2.01 & 1.30 & 1.02 \\
\hline N5 & 342 & 305 & 1.84 & 1.63 & 2.04 & 2.21 & 2.31 & 1.40 & 1.21 \\
\hline N5Bis & 351 & 313 & 1.89 & 1.67 & 2.09 & 2.27 & 2.37 & 1.46 & 1.25 \\
\hline N6 & 185 & 165 & 1.76 & 1.69 & 2.04 & 2.29 & 2.39 & 1.45 & 1.20 \\
\hline N6Bis & 166 & 148 & 1.58 & 1.52 & 1.83 & 2.05 & 2.14 & 1.25 & 1.08 \\
\hline \multicolumn{3}{|c|}{ AVG } & 1.69 & 1.52 & 1.90 & 2.05 & 2.15 & 1.29 & 1.11 \\
\hline \multicolumn{3}{|c|}{ STD } & 0.14 & 0.17 & 0.15 & 0.22 & 0.23 & 0.15 & 0.12 \\
\hline \multicolumn{3}{|c|}{$5 \%$ Percentile } & 1.54 & 1.29 & 1.72 & 1.74 & 1.82 & 1.11 & 0.95 \\
\hline
\end{tabular}

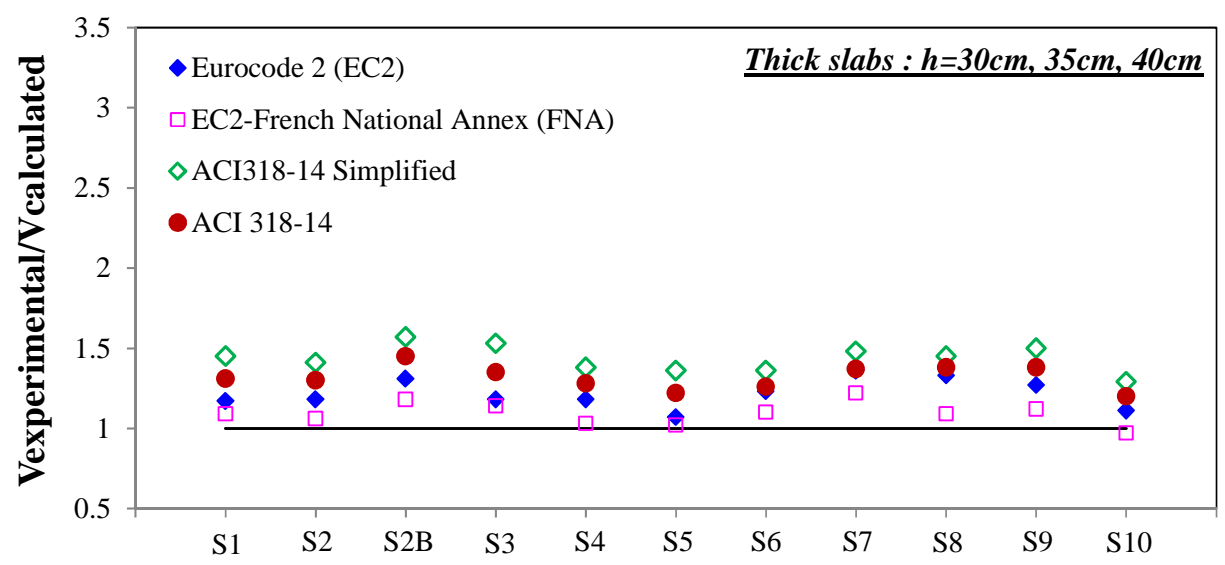

Figure 6: Thick slabs: experimental results Vs EC2, French approach and ACI 318-14. 


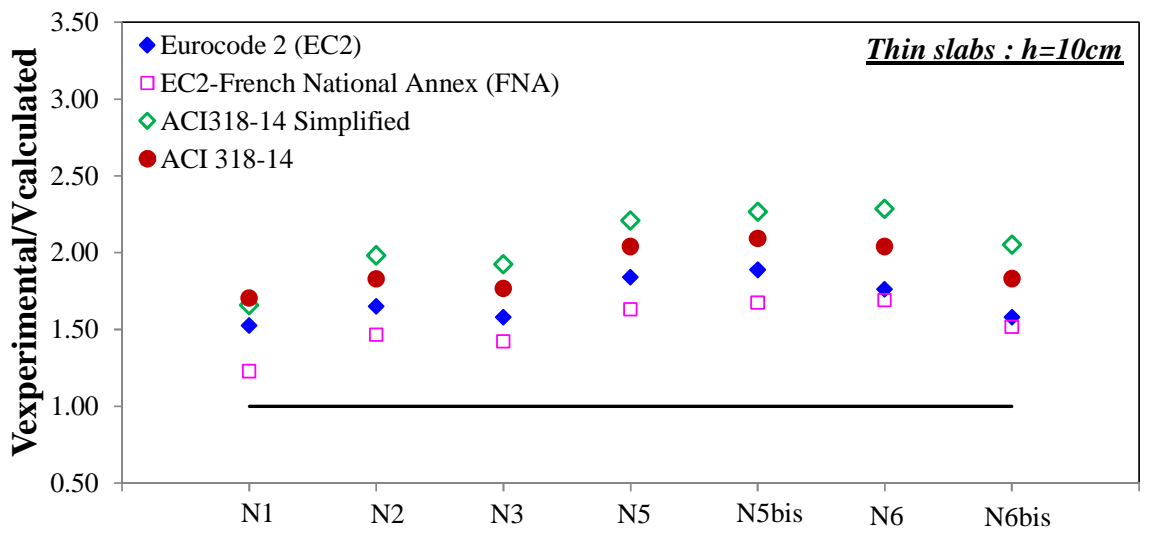

Figure 7: Thin slabs: experimental results Vs EC2, French approach and ACI 318-14.

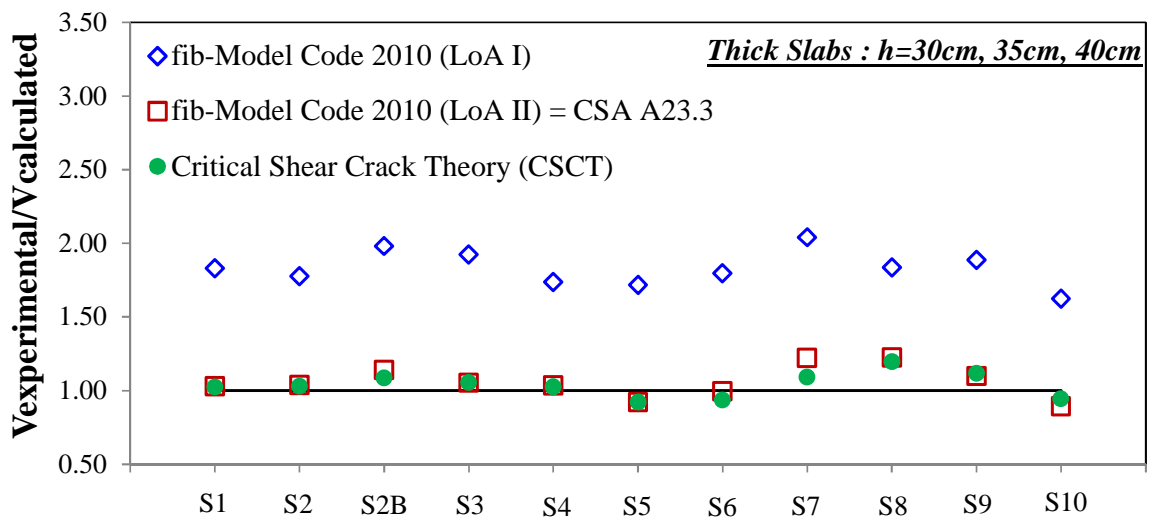

Figure 8: Thick slabs: experimental results Vs Model Code 2010 (MC) and CSCT.

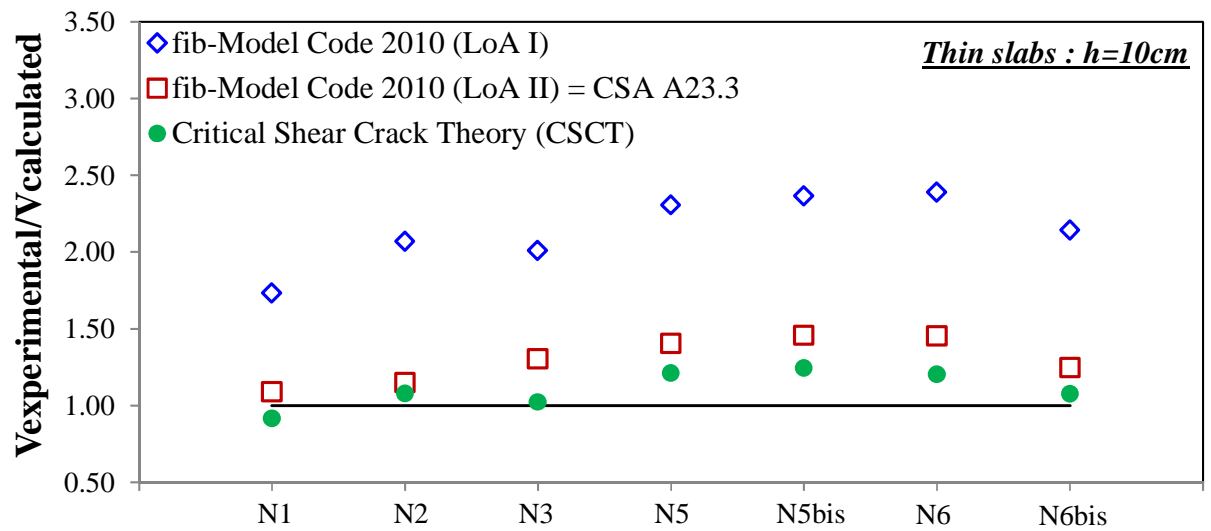

Figure 9: Thin slabs: comparisons of test results from Model Code 2010 (MC) and Critical Shear Crack Theory (CSCT). 

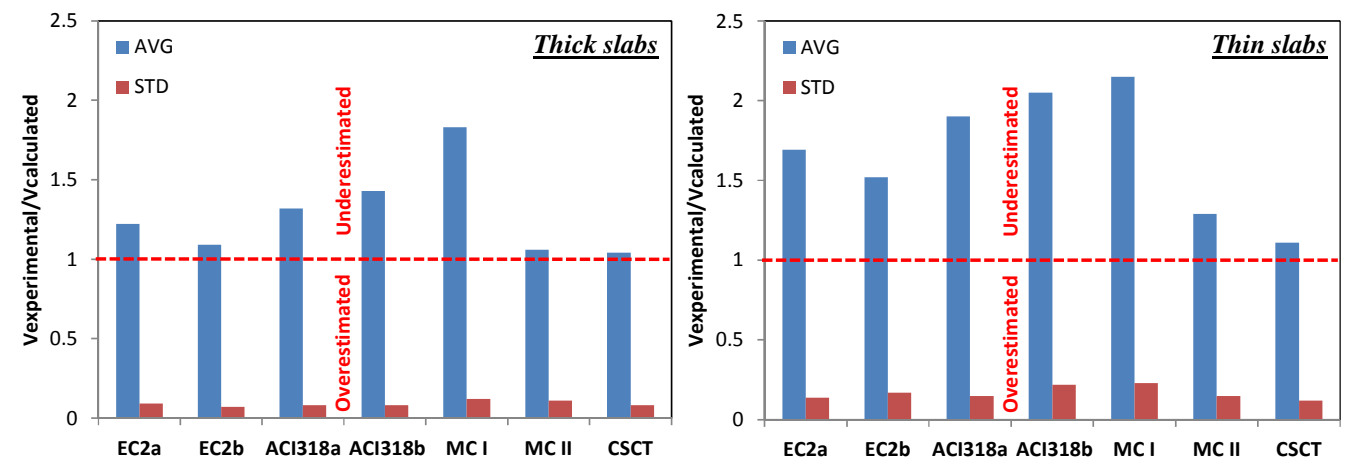

Figure 10: Comparisons between models: illustration of the conservatism degree

\section{Conclusions}

This paper presents a comparative study of all the main analytical methods to estimate the shear capacity of thick and thin RC slabs without stirrups. The experimental results are compared to the Eurocode 2, French National Annex, ACI 318 and its simplified version, Fib Model Code 2010 using level of approximation LoA I, LoA II, with LoA II equivalent to the Canadian standard CSA A23.3, and Critical Shear Crack Theory CSCT, basis of Swiss standard SIA 262 design models. These comparisons delivered valuable information for engineers that design thick or thin RC slabs under shear loading, as currently, there is not yet a general agreement on a design model giving the shear strength of RC structures not containing shear reinforcement. The following conclusions were drawn:

- The French National Annex approach FNA resulted in shear capacities predictions that are very close to the experimental values. However, the Eurocode 2 approach resulted in an underestimation.

- The shear strengths predicted by ACI 318-14 and ACI simplified also gave underestimations when confronted with all the experimental results. 
- The Fib Model Code 2010 using level of approximation LoA II and the Critical Shear Crack Theory CSCT gave the best agreements when compared with the experimental results. The Model Code 2010 with the first level of approximation (LoA I) appeared as very conservative. The fib Model Code 2010 based on MCFT and Critical Shear Crack Theory CSCT provisions for shear represent a significant evolution in standardization with the abandonment of empirically based models in favor of physically sound models. Empirical formulations as Eurocode 2 and ACI 318 are less accurate and may neglect the role of some shear governing parameters. Therefore, MCFT based models (fib Model Code 2010, CSA, AASHTO LRFD) or CSCT based models (SIA 262) have the resources to create a modification in the way shear is treated at the international level and a unified international approach could be drawn from these models.

- Compared to prediction levels for thick slabs $(30 \mathrm{~cm}, 35 \mathrm{~cm}$ and $40 \mathrm{~cm})$, for thin $10 \mathrm{~cm}$ slabs, the predictions for all models seem more conservative.

In a future work, own amendments to the standard formulas should be proposed based on the experimental results. In particular a modification of the Eurocode 2, ACI 318-14, ACI simplified and Fib Model Code 2010 using level of approximation LoA I (MC I) should be proposed to make it more accurate and more physical while taking into account the effect of all shear parameters (for example, the effect of aggregates size may be taken into account).

\section{Acknowledgements}

This work was funded by a contract from EDF SEPTEN.

\section{References}

AASHTO. 2004. AASHTO LRFD bridge design specifications and commentary, AASHTO LRFD-04, 3rd Ed., Washington, D.C. 
ACI-ASCE Committee 326, “Shear and Diagonal Tension,” ACI J. Proc. V59 No1 23 Jan Feb Mar 1962 Pp 1-30 277-334 352-396 Discuss. Clos., pp. 1323-1349, 1962.

ACI Comittee 318, 2014. Building Code Requirements for Structural Concrete (ACI 318-14) and Commentary.

ASCE-ACI Committee 445 on Shear and Torsion, 1998. Recent Approaches to Shear Design of Structural Concrete. J. Struct. Eng. 124, 1375-1417. doi:10.1061/(ASCE)0733-9445(1998)124:12(1375)

Balázs G. L., “A historical review of shear,” Bulletin, vol. 57, pp. 1-13, 2010.

Bazant, Z. P., Yu, Q., Gerstle, W., Hanson, J., \& Ju, J. W., "Justification of ACI 446 code provisions for shear design of reinforced concrete beams,” ACI Structural Journal, 104(5), 601, 2007.

Belletti B., Damoni C., Hendriks M. A., and A. de Boer, “Analytical and numerical evaluation of the design shear resistance of reinforced concrete slabs," Struct. Concr., vol. 15, no. 3, pp. 317-330, 2014.

Bentz E. C., F. J. Vecchio, and M. P. Collins, "Simplified modified compression field theory for calculating shear strength of reinforced concrete elements,” ACI Struct. J., vol. 103, no. 4, p. 614, 2006.

Bentz E. C. and M. P. Collins, "Development of the 2004 Canadian Standards Association (CSA) A23. 3 shear provisions for reinforced concrete," Can. J. Civ. Eng., vol. 33, no. 5, pp. 521-534, 2006.

Bresler, B., \& MacGregor, J. G., "Review of concrete beams failing in shear," Journal of the Structural Division, 93(1), 343-372, 1967.

Bresler B. and Scordelis A. C., "Shear strength of reinforced concrete beams," in Journal Proceedings, 1963, vol. 60, pp. 51-74.

Brown, M. D., Bayrak, O., Jirsa, J. O.: Design for shear based on loading conditions. ACI Structural Journal, vol. 103, No. 4, 2006, pp. 541-550.

Bui, T.T., Limam, A., Nana, W.S.A., Ferrier, E.,, Bost, M., Bui, Q.B., 2017: «Evaluation of one-way shear behavior of reinforced concrete slabs: Experimental and Numerical Analysis». European Journal of Environmental and Civil Engineering., pp. 1-27.

CEN, 2005. Eurocode 2: Design of concrete structures - Part 1-1: General rules and rules for buildings. EN 1992-1-1:2005. Bruss Belg Com Eur Norm.

Collins, M. P., Bentz, E. C., Sherwood, E. G.: Where is Shear Reinforcement Required? Review of Research Results and Design Procedures. ACI Structural Journal, vol. 105, No. 5, 2008, pp. 590-600. 
CSA Committee A23.3: Design of Concrete Structures. Canadian Standard, Mississauga, Ontario, Canada, 2004.

FD P 18-717, 2013. Eurocode 2 - Calcul des structures en béton - Guide d'application des normes NF EN 1992.

Fib Model Code 2010, "Fédération Internationale du Béton (fib)-Final Draft," Vol 1 Bull. 65 Vol 2 Bull. 66 Lausanne Switz., 2012.

Joint Committee on Concrete and Reinforced Concrete, "Final report on concrete and reinforced concrete," Proc. Am. Soc. Civ. Eng. 4210, pp. 167-1708, 1916.

Khaja M. N. and E. G. Sherwood, "Does the shear strength of reinforced concrete beams and slabs depend upon the flexural reinforcement ratio or the reinforcement strain? 1," Can. J. Civ. Eng., vol. 40, no. 11, pp. 1068-1081, 2013.

König, G., Fischer, J., "Model uncertainties concerning design equations for the shear capacity of concrete members without shear reinforcement," CEB Bull. 224, 49-100, 1995.

Lantsoght, E. O., van der Veen, C., \& Walraven, J. C., "Shear capacity of slabs and slab strips loaded close to the support," ACI SP-287, Recent Development in Reinforced Concrete Slab Analysis, Design and Serviceability, 5-1, 2012.

Lubell, A.S., Bentz, E.C., Collins, M.P., "Shear reinforcement spacing in wide members,". ACI Struct. J. 106, 205, 2009.

Marí, A., Bairán, J., Cladera, A., Oller, E., \& Ribas, C., "Shear-flexural strength mechanical model for the design and assessment of reinforced concrete beams," Structure and Infrastructure Engineering, 11(11), 1399-1419, 2015.

Muttoni, A., and Schwartz, J., "Behaviour of Beams and Punching in Slabs without Shear Reinforcement," Proceedings of the IABSE Colloquium, V. 62, Stuttgart, Germany, 1991, pp. 703-708.

Muttoni, A., "Shear and punching strength of slabs without shear reinforcement,". Beton- Und Stahlbetonbau, 98(2), 74-84, 2003a.

Muttoni, Aurelio., "Eléments sans armature d'effort tranchant". Documentation SIA, D 0182 Introduction à la norme SIA 262, $2003 \mathrm{~b}$. 
Muttoni, Aurelio, \& Ruiz, M. F., "Shear strength of members without transverse reinforcement as function of critical shear crack width,” ACI Structural Journal, 105(2), 163, 2008.

Muttoni, Aurelio, \& Ruiz, M. F., “Levels-of-Approximation Approach in Codes of Practice,” Structural Engineering International, 22(2), 190-194, 2012.

Nana, W.S.A., Bui, T.T., Limam, A., Abouri, S., 2017. Experimental and Numerical Modelling of Shear Behaviour of Full-scale RC Slabs Under Concentrated Loads. Structures 10, 96-116. doi:10.1016/j.istruc.2017.02.004

Regan P. E., "Shear resistance of members without shear reinforcement; proposal for CEB Model Code MC90,” Polytech. Cent. Lond. Lond. UK, pp. 1-28, 1987

Regan, P. E., \& Rezai-Jorabi, H., "Shear resistance of one-way slabs under concentrated loads," Structural Journal, 85(2), 150-157, 1988.

Shioya, T., Iguro, M., Nojiri, Y., Akiyama, H., \& Okada, T.,"Shear strength of large reinforced concrete beams," Special Publication, 118, 259-280, 1990.

SIA. SIA 262 - construction en béton; Société Suisse des Ingénieurs et Architectes; révision partielle de 2012Zürich; Suisse ; 2012(102 p).

Timoshenko S., S. Woinowsky-Krieger, Theory of Plates and Shells, McGrawHill, 1959.

Vecchio F. J. and Collins M. P., "The modified compression-field theory for reinforced concrete elements subjected to shear.," ACI J, vol. 83, no. 2, pp. 219-231, 1986.

Walraven J. C., "Minimum Shear Capacity of Reinforced Concrete Slabs without Shear Reinforcement: The Value of vmin,” Delft Univ. Technol. Dutch, pp. 1-20, 2013.

Walraven, J. C., "Fundamental analysis of aggregate interlock,". Journal of the Structural Division, 107(11), 2245-2270, 1981. 